İsletme Bilimi Dergisi 2020

Cilt:8 Sayı:1
SAKARYA

ÜNIVERSITESI
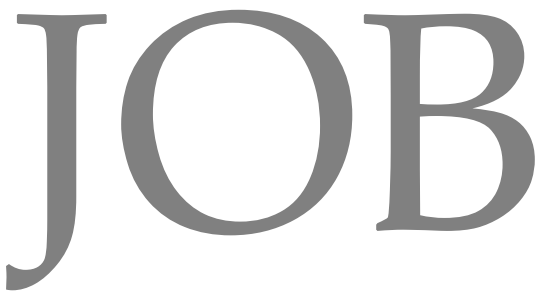

İşletme Bilimi Dergisi

The Journal of Business Science

Sakarya Üniversitesi / Sakarya University İşletme Fakültesi / Sakarya Business School

$\begin{array}{ll}\text { Cilt/Volume } & : 8 \\ \text { Say1/Issue } & : 1 \\ \text { Yil/Year } & : 2020\end{array}$

ISSN: 2148-0737

DOI: 10.22139/jobs 
İşletme Bilimi Dergisi 2020 Cilt:8 Sayı:1

ii

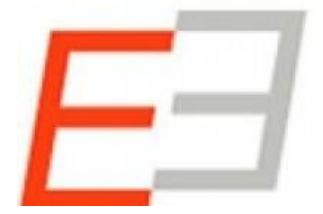

Akademilk Ansustumalari Indeksi
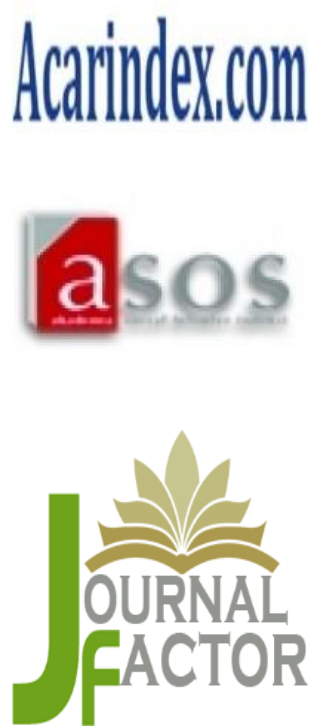
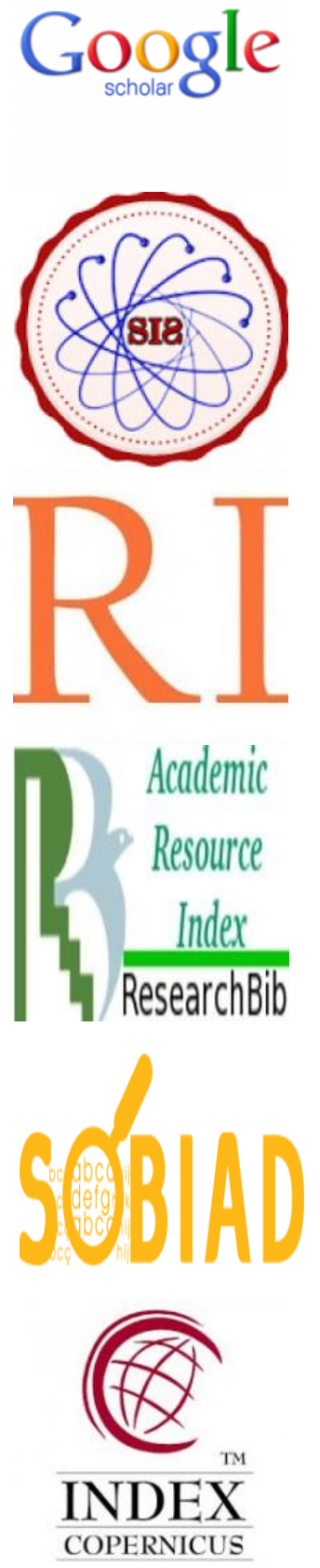
Kurucu Sahip/Founder

Issletme Bilimi Dergisi

2020

Prof. Dr. Gültekin YILDIZ

Cilt:8 Sayı:1

Imtiyaz Sahibi / Owner

Prof. Dr. Kadir ARDIÇ

Editör / Editor

Prof. Dr. Mahmut AKBOLAT

Editör Yardımcıları / Assoc. Editors

Prof. Dr. Mustafa Cahit UNGAN

Mizanpaj Editörü / Layout Editor

Arş. Gör. Dr. Özgün ÜNAL

\section{DanışmaKurulu/Advisory Board}

Prof. Dr. Ahmet Vecdi CAN

Prof. Dr. Bülent SEZEN

Prof. Dr. Dilaver TENGİLIMOĞLU

Prof. Dr. Erman COŞKUN

Prof. Dr. Kadir ARDIÇ

Prof. Dr. Mehmet BARCA

Prof. Dr. Nihat ERDOĞMUŞ

Prof. Dr. Orhan BATMAN

Prof. Dr. Recai COŞKUN

Prof. Dr. Remzi ALTUNIŞIK

Prof. Dr. Selahattin KARABINAR

Prof. Dr. Sidika KAYA

Prof. Dr. Şevki ÖZGENER

Prof. Dr. Türker BAŞ

Doç. Dr. Surendranath Rakesh JORY
Sakarya Üniversitesi

Gebze Yüksek Teknoloji Enstitüsü

Atılım Üniversitesi

İzmir Bakırçay Üniversitesi

Sakarya Üniversitesi

Ankara Sosyal Bilimler Üniversitesi

İstanbul Şehir Üniversitesi

Sakarya Üniversitesi

İzmir Bakırçay Üniversitesi

Sakarya Üniversitesi

İstanbul Üniversitesi

Hacettepe Üniversitesi

Nevşehir Üniversitesi

Galatasaray Üniversitesi

Southampton Üniversitesi 
İşletme Bilimi Dergisi

2020

Cilt:8 Sayı:1
Yayın Kurulu / Editorial Board

\author{
Prof. Dr. Kadir ARDIÇ \\ Prof. Dr. Mahmut AKBOLAT \\ Prof. Dr. Mustafa Cahid ÜNĞAN
}

Sekreterya / Secreteria

Arş. Gör. Dr. Özgün ÜNAL
Arş. Gör. Mustafa AMARAT
Arş. Gör. Ayhan DURMUŞ

Dergimize yayınlanmak üzere gönderilen makalelerin yazımında etik ilkelere uyulduğu ve yazarların ilgili etik kurulundan gerekli yasal onayları aldığı varsayılmaktadır. Bu konuda sorumluluk tamamen yazarlara aittir. İşletme Bilimi Dergisi'nde yer alan makalelerin bilimsel sorumluluğu yazara aittir. Yayınlanmış eserlerden kaynak gösterilmek suretiyle alıntı yapılabilir.

It is assumed that the articles submitted for publication in our journal are written in ethical principles and the authors have obtained the necessary legal approvals from the relevant ethics committee. The responsibility of this matter belongs to the authors. Scientific responsibility for the articles belongs to the authors themselves. Published articles could be cited in other publications provided that full referenceisgiven.

İşletme Bilimi Dergisi; www.dergipark.gov.tr/jobs SakaryaÜniversitesi İşletme Fakültesi jobs@sakarya.edu.tr Esentepe Kampüsü 54187 Serdivan/SAKARYA 


\section{Hakemler/ Reviewers}

Prof. Dr. Abdullah Naralan Prof. Dr. Ahmet Vecdi Can Prof. Dr. Adem Öğüt

Prof. Dr. Adnan Akın

Prof. Dr. Ahmet Bardakçı

Prof. Dr. Aykut Hamit Turan

Prof. Dr. Ayşe İrmiş

Prof. Dr. Bayram Şahin

Prof. Dr. Bayram Topal

Prof. Dr. Bayram Zafer Erdoğan

Prof. Dr. Dilaver Tengilimoğlu

Prof. Dr. Durmuş Acar

Prof. Dr. Ekrem Tatoğlu

Prof. Dr. Erman Coşkun

Prof. Dr. Fatih Ertaş

Prof. Dr. Gülten Gümüştekin

Prof. Dr. Halit Keskin

Prof. Dr. Hasan Tutar

Prof. Dr. Haydar Sur

Prof. Dr. Himmet Karadal

Prof. Dr. İsmet Şahin

Prof. Dr. İsmet Hakkı Eraslan

Prof. Dr. Kadir Ardıç

Prof. Dr. Kıymet Çalıyurt

Prof. Dr. Mehmet Akif Çukurçayır

Prof. Dr. Mehmet Adak

Prof. Dr. Mehmet Barca

Prof. Dr. Mehmet Sarışık

Prof. Dr. Mehmet Selami Yıldız

Prof. Dr. Muhsin Halis

Prof. Dr. Musa Özata

Prof. Dr. Mustafa Cahit Ungan

Prof. Dr. Nazan Günay

Prof. Dr. Necdet Şensoy

Prof. Dr. Nejat Bozkurt

Prof. Dr. Nilgün Sarıkaya

Prof. Dr. Nuran Cömert

Prof. Dr. Oğuz Türkay

Prof. Dr. Orhan Batman

Prof. Dr. Ömer Torlak

Prof. Dr. Özgür Uğurluoğlu

Prof. Dr. Recai Coşkun

Prof. Dr. Recep Pekdemir

Prof. Dr. Remzi Altunışık

Prof. Dr. Ruziye Cop

Prof. Dr. Selahattin Karabınar

Prof. Dr. Selman Aziz Erdem

Prof. Dr. Serap Benligiray
Recep Tayyip Erdoğan Üniversitesi

Sakarya Üniversitesi

Selçuk Üniversitesi

Kırıkkale Üniversitesi

Pamukkale Üniversitesi

Sakarya Üniversitesi

Pamukkale Üniversitesi

Hacettepe Üniversitesi

Sakarya Üniversitesi

Anadolu Üniversitesi

Gazi Üniversitesi

Süleyman Demirel Üniversitesi

Bahçeşehir Üniversitesi

İzmir Bakırçay Üniversitesi

Gaziosmanpaşa Üniversitesi

Dumlupınar Üniversitesi

Gebze Yüksek Teknoloji Enstitüsü

Eskişehir Anadolu Üniversitesi

Nişantaşı Üniversitesi

Aksaray Üniversitesi

Hacettepe Üniversitesi

Düzce Üniversitesi

Sakarya Üniversitesi

Trakya Üniversitesi

Selçuk Üniversitesi

İstanbul Üniversitesi

Yıldırım Beyazıt Üniversitesi

Sakarya Uygulamalı Bilimler Üniversitesi

Düzce Üniversitesi

Kocaeli Üniversitesi

Ahi Evran Üniversitesi

Sakarya Üniversitesi

Ege Üniversitesi

Marmara Üniversitesi

Marmara Üniversitesi

Sakarya Üniversitesi

Marmara Üniversitesi

Sakarya Uygulamalı Bilimler Üniversitesi

Sakarya Uygulamalı Bilimler Üniversitesi

Karatay Üniversitesi

Hacettepe Üniversitesi

İzmir Bakırçay Üniversitesi

İstanbul Üniversitesi

Sakarya Üniversitesi

Abant İzzet Baysal Üniversitesi

İstanbul Üniversitesi

Kocaeli Üniversitesi

Anadolu Üniversitesi
İşletme Bilimi Dergisi

2020

Cilt:8 Sayı:1 
İşletme Bilimi Dergisi

2020

Cilt:8 Sayı:1
Prof. Dr. Serap İncaz

Prof. Dr. Serdar Özkan

Prof. Dr. Şakir Sakarya

Prof. Dr. Şevki Özgener

Prof. Dr. Suayyip Calış

Prof. Dr. Sıdıka Kaya

Prof. Dr. Sima Nart

Prof. Dr. Şuayip Özdemir

Prof. Dr. Tamer Uğur

Prof. Dr. Türker Baş

Prof. Dr. Ümit Gücenme Gençoğlu

Prof. Dr. Ümmühan Aslan

Prof. Dr. Vasfi Haftacı

Prof. Dr. Yıldız Özerhan

Prof. Dr. Yusuf Çelik

Doç. Dr. Abdurrahman Benli

Doç.Dr. Adem Baltacı

Doç. Dr. Adem Sağır

Doç. Dr. Ali Taş

Doç. Dr. Aşkın Özdağoğlu

Doç. Dr. Behçet Yalın Özkara

Doç. Dr. Bora Yenihan

Doç. Dr. Bora Yıldız

Doç. Dr. Buket Bora Semiz

Doç. Dr. Burcu Adıgüzel Mercangöz

Doç. Dr. Burcu Candan

Doç. Dr. Burhanettin Zengin

Doç. Dr. Buket Bora Semiz

Doç. Dr. Cavit Yeşilyurt

Doç. Dr. Cemal Sezer

Doç. Dr. Cemal İyem

Doç. Dr. Ece Armağan

Doç. Dr. Emrah Özkul

Doç. Dr. Engin Dinç

Doç. Dr. Erdoğan Kaygın

Doç. Dr. Erkan Erdemir

Doç. Dr. Faruk Anıl Konuk

Doç. Dr. Fatih Geçti

Doç. Dr. Ferudun Kaya

Doç. Dr. Fikret Çankaya

Doç. Dr. Fuat Man

Doç. Dr. Gülfen Tuna

Doç. Dr. Hakan Murat Arslan

Doç. Dr. Hakan Tunahan

Doç. Dr. Haluk Bengü

Doç. Dr. Hasan Ayyıldız

Doç. Dr. Hasan Latif

Doç. Dr. Harun Kırılmaz
Hakemlerl Reviewers

Nişantaşı Üniversitesi

İzmir Ekonomi Üniversitesi

Balıkesir Üniversitesi

Nevşehir Üniversitesi

Sakarya Üniversitesi

Hacettepe Üniversitesi

Sakarya Üniversitesi

Afyon Kocatepe Üniversitesi

Atatürk Üniversitesi

Galatasaray Üniversitesi

Uludağ Üniversitesi

Bilecik Şeyh Edebali Üniversitesi

Kocaeli Üniversitesi

Gazi Üniversitesi

Hacettepe Üniversitesi

Sakarya Üniversitesi

İstanbul Medeniyet Üniversitesi

Karabük Üniversitesi

Sakarya Üniversitesi

Dokuz Eylül Üniversitesi

Eskişehir Osmangazi Üniversitesi

Kırklareli Üniversitesi

İstanbul Üniversitesi

Bilecik Şeyh Edebali Üniversitesi

İstanbul Üniversitesi

Kocaeli Üniversitesi

Sakarya Uygulamalı Bilimler Üniversitesi

Bilecik Şeyh Edebali Üniversitesi

Atatürk Üniversitesi

Sakarya Üniversitesi

Adnan Menderes Üniversitesi

Adnan Menderes Üniversitesi

Karadeniz Teknik Üniversitesi

Karadeniz Teknik Üniversitesi

Kafkas Üniversitesi

İstanbul Şehir Üniversitesi

Sakarya Üniversitesi

Yalova Üniversitesi

Abant İzzet Baysal Üniversitesi

Karadeniz Teknik Üniversitesi

Sakarya Üniversitesi

Sakarya Üniversitesi

Düzce Üniversitesi

Sakarya Üniversitesi

Niğde Üniversitesi

Karadeniz Teknik Üniversitesi

Sakarya Uygulamalı Bilimler Üniversitesi

Sakarya Üniversitesi 


\section{Hakemler/ Reviewers}

Doç. Dr. Hayrettin Zengin

Doç. Dr. Kazım Ozan Özer

Doç. Dr. Kemal Can Kılıç

Doç. Dr. Kubilay Özyer

Doç. Dr. Kurtuluş Kaymaz

Doç. Dr. Mahmut Hızıroğlu

Doç. Dr. Mehmet Ali Alan

Doç Dr. Mehmet Altınöz

Doç. Dr. Mehmet Saraç

Doç. Dr. Mesut Çimen

Doç. Dr. Mehmet Han Ergüven

Doç. Dr. Muammer Mesci

Doç. Dr. Musa Said Döven

Doç. Dr. Mustafa Cahid Ünğan

Doç. Dr. Mustafa Kemal Demirci

Doç. Dr. Mutlu Başaran Öztürk

Doç. Dr. Müjdat Özmen

Doç. Dr. Nevran Karaca

Doç. Dr. Nihal Sütütemiz

Doç. Dr. Niyazi Kurnaz

Doç. Dr. Oğuz Işık

Doç. Dr. Ömer Okan Fettahlıŏlu

Doç. Dr. Özlem Balaban

Doç. Dr. Ötüken Senger

Doç. Dr. Ramazan Aksoy

Doç. Dr. Recep Yilmaz

Doç. Dr. Safiye Sencer

Doç. Dr. Üyesi Samet Güner

Doç. Dr. Seçil Taştan

Doç. Dr. Sedat Bostan

Doç. Dr. Selami Özcan

Doç. Dr. Senay Yürür

Doç. Dr. Serkan Şengül

Doç. Dr. Sinan Esen

Doç. Dr. Şerife Subaşı

Doç. Dr. Şevki Ulama

Doç. Dr. Sinan Esen

Doç. Dr. Tansel Hacıhasanoğlu

Doç. Dr. Taşkın Kılıç

Doç. Dr. Tuncay Yilmaz

Doç. Dr. Umut Koç

Doç. Dr. Umut Sanem Çiftçi

Doç. Dr. Ümit Alnıaçık

Doç. Dr. Yasemin Özdemir

Doç. Dr. Yasin Şehitoğlu

Doç. Dr. Yunus Emre Öztürk

Dr. Öğr. Üyesi A. Mohammed Abubakar

Dr. Öğr. Üyesi Abit Balın
Sakarya Üniversitesi

Nişantaşı Üniversitesi

Çukurova Üniversitesi

Gaziosmanpaşa Üniversitesi

Uludağ Üniversitesi

Ankara Sosyal Bilimler Üniversitesi

Cumhuriyet Üniversitesi

Havettepe Üniversitesi

İstanbul Üniversitesi

Acıbadem Üniversitesi

Kırklareli Üniversitesi

Düzce Üniversitesi

Osmangazi Üniversitesi

Sakarya Üniversitesi

Dumlupınar Üniversitesi

Niğde Üniversitesi

Osmangazi Üniversitesi

Sakarya Üniversitesi

Sakarya Üniversitesi

Kütahya Dumlupınar Üniversitesi

Hacettepe Üniversitesi

Sütçü İmam Üniversitesi

Sakarya Üniversitesi

Kafkas Üniversitesi

Bülent Ecevit Üniversitesi

Sakarya Üniversitesi

Sakarya Üniversitesi

Sakarya Üniversitesi

Marmara Üniversitesi

Ordu Üniversitesi

Yalova Üniversitesi

Yalova Üniversitesi

Abant İzzet Baysal Üniversitesi

Sakarya Uygulamalı Bilimler Üniversitesi

Bilecik Şeyh Edebali Üniversitesi

Sakarya Uygulamalı Bilimler Üniversitesi

Sakarya Uygulamalı Bilimler Üniversitesi

Bozok Üniversitesi

Ordu Üniversitesi

Sakarya Üniversitesi

Osmangazi Üniversitesi

İzmir Bakırçay Üniversitesi

Kocaeli Üniversitesi

Sakarya Üniversitesi

Yıldız Teknik Üniversitesi

Selçuk Üniversitesi

Aksaray Üniversitesi

İstanbul Üniversitesi
İsletme Bilimi Dergisi

2020

Cilt:8 Sayı:1 


\section{Işletme Bilimi Dergisi}

2020

Cilt:8 Sayı:1

Viii

\section{Hakemler/ Reviewers}

Dr. Öğr. Üyesi Ali Özgür Karagülle

Dr. Öğr. Üyesi Adem Akbıyık

Dr. Öğr. Üyesi Ahmet Kar

Dr. Öğr. Üyesi Ahmet Yağmur Ersoy

Dr. Öğr. Üyesi Ali Coşkun

Dr. Öğr. Üyesi Ali Yılmaz

Dr. Öğr. Üyesi Algın Okursoy

Dr. Öğr. Üyesi Alper Kurnaz

Dr. Öğr. Üyesi Ayhan Serhateri

Dr. Öğr. Üyesi Aydoğan Durmuş

Dr. Öğr. Üyesi Behçet Yalın Özkara

Dr. Öğr. Üyesi Berna Eren

Dr. Öğr. Üyesi Ceren Giderler Atalay

Dr. Öğr. Üyesi Derya Ergun Özler

Dr. Öğr. Üyesi Dilek Özceylan

Dr. Öğr. Üyesi Ebru Demirci

Dr. Öğr. Üyesi Ebru Özlem Bilgin

Dr. Öğr. Üyesi Emrah Özsoy

Dr. Öğr. Üyesi Emre Oruç

Dr. Öğr. Üyesi Ersin Irk

Dr. Öğr. Üyesi Esra Dil

Dr. Öğr. Üyesi Fatma Gamze Bozkurt

Dr. Öğr. Üyesi Fatih Budak

Dr. Öğr. Üyesi Fatih Şantaş

Dr. Öğr. Üyesi Ferda Alper Ay

Dr. Öğr. Üyesi Firat Altınkaynak

Dr. Öğr. Üyesi Filiz Konuk

Dr. Öğr. Üyesi Füsun Küçükbay Gökalp

Dr. Öğr. Üyesi Gökçe Cerev

Dr. Öğr. Üyesi Gökhan GÜRLER

Dr. Öğr. Üyesi Gülcan Şantaş

Dr. Öğr. Üyesi Hacı Mehmet Yıldırım

Dr. Öğr. Üyesi Halil İbrahim Cebeci

Dr. Öğr. Üyesi İbrahim Taha Dursun

Dr. Öğr. Üyesi İrfan Usta

Dr. Öğr. Üyesi İsa Demirkol

Dr. Öğr. Üyesi İsmail Şimşir

Dr. Öğr. Üyesi Mihriban Cindiloğlu

Dr. Öğr. Üyesi Lütfi Mustafa Şen

Dr. Öğr. Üyesi Metin Bayram

Dr. Öğr. Üyesi Murat Ayanoğlu

Dr. Öğr. Üyesi Mustafa Kenan Erkan

Dr. Öğr. Üyesi Mustafa Yıldırım

Dr. Öğr. Üyesi Murat Doğdubay

Dr. Öğr. Üyesi Nermin Akyel

Dr. Öğr. Üyesi Nesrin Akca

Dr. Öğr. Üyesi Nurperihan Tosun

Dr. Öğr. Üyesi Onur Dirlik
İstanbul Üniversitesi

Sakarya Üniversitesi

Kırıkkale Üniversitesi

Sakarya Üniversitesi

Boğaziçi Üniversitesi

Kırıkkale Üniversitesi

Adnan Menderes Üniversitesi

Abant İzzet Baysal Üniversitesi

Sakarya Üniversitesi

İstinye Üniversitesi

Eskişehir Osmangazi Üniversitesi

Acıbadem Üniversitesi

Dumlupınar Üniversitesi

Dumlupınar Üniversitesi

Sakarya Üniversitesi

İstanbul Üniversitesi

Sakarya Uygulamalı Bilimler Üniversitesi

Sakarya Üniversitesi

Bilecik Şeyh Edebali Üniversitesi

Gaziosmanpaşa Üniversitesi

Sakarya Üniversitesi

Sakarya Üniversitesi

Kilis 7 Aralık Üniversitesi

Bozok Üniversitesi

Cumhuriyet Üniversitesi

Sakarya Uygulamalı Bilimler Üniversitesi

Sakarya Üniversitesi

Celal Bayar Üniversitesi

Frrat Üniversitesi

Sakarya Üniversitesi

Bozok Üniversitesi

Çanakkale Onsekiz Mart Üniversitesi

Sakarya Üniversitesi

Sakarya Üniversites

Gaziosmanpaşa Üniversitesi

Kırıkale Üniversitesi

Sakarya Uygulamalı Bilimler Üniversitesi

Hitit Üniversitesi

Sakarya Uygulamalı Bilimler Üniversitesi

Sakarya Üniversitesi

Sakarya Üniversitesi

Sakarya Üniversitesi

Sakarya Üniversitesi

Balıkesir Üniversitesi

Sakarya Uygulamalı Bilimler Üniversitesi

Kırıkkale Üniversitesi

Cumhuriyet Üniversitesi

Osmangazi Üniversitesi 


\section{Hakemler/ Reviewers}

Dr. Öğr. Üyesi Orhan Kandemir Dr. Öğr. Üyesi Osman Uslu Dr. Öğr. Üyesi Özer Uygun Dr. Öğr. Üyesi Pınar Memiş Sağır Dr. Öğr. Üyesi Sedat Durmuşkaya Dr. Öğr. Üyesi Selma Kılıç Kırılmaz Dr. Öğr. Üyesi Sema Polatçı Dr. Öğr. Üyesi Sema Yiğit Dr. Öğr. Üyesi Sema Ülkü Akpınar Dr. Öğr. Üyesi Semih Okutan Dr. Öğr. Üyesi Serkan Deniz Dr. Öğr. Üyesi Sümeyra A. Danışman Dr. Öğr. Üyesi Şevki Ulama Dr. Öğr. Üyesi Şuayyip Doğuş Demirci Dr. Öğr. Üyesi Şule Yıldız Dr. Öğr. Üyesi Tarık Semiz Dr. Öğr. Üyesi Tayfun Yılmaz Dr. Öğr. Üyesi Tuncay Turaboğlu Öğr. Gör. Dr. Aykut Yılmaz Öğr. Gör. Dr. Hüseyin İskender Öğr. Gör. Dr. İlker Calayoğlu Arş. Gör. Dr. Seda Aydan
Kastamonu Üniversitesi

Sakarya Üniversitesi

Sakarya Üniversitesi

Sakarya Üniversitesi

Sakarya Uygulamalı Bilimler Üniversitesi Sakarya Uygulamalı Bilimler Üniversitesi Gaziosmanpaşa Üniversitesi

Ordu Üniversitesi

Sakarya Üniversitesi

Sakarya Üniversitesi

Yalova Üniversitesi

Mevlana Üniversitesi

Sakarya Üniversitesi

İzmir Kâtip Çelebi Üniversitesi

Sakarya Üniversitesi

Bilecik Şeyh Edebali Üniversitesi

Mehmet Akif Ersoy Üniversitesi

Mersin Üniversitesi

Sakarya Uygulamalı Bilimler Üniversitesi

Sakarya Uygulamalı Bilimler Üniversitesi

Okan Üniversitesi

Hacettepe Üniversitesi
İşletme Bilimi Dergisi

2020

Cilt:8 Sayı:1 
İşletme Bilimi Dergisi

2020

Cilt:8 Sayı:1
Değerli Bilim İnsanları,

İşletme Bilimi Dergisinin 8. Cilt 1. Sayısını yayınlamaktan dolayı mutluluk duyuyoruz. Yedi yillık yayın hayatımızda olduğu gibi bu sayıda da farklı disiplinlerden gelen makaleler ile sizlere zengin bir içerik sunuyoruz. 8. Cilt 1. Sayımız toplam 8 makale ile yayınlanmaktadır. Yayınlanan makaleler, Sağlik Yönetim, Turizm İşletmeciliği, Muhasebe ve Finansman, Issletme Yönetimi ve Pazarlama gibi çeşitli alanlardan gelmiştir.

Sayımızın ilk makalesi Arş. Gör. Gülsüm Şeyma KOCA ve Prof. Dr. Yusuf ÇELIK tarafindan kaleme alınan "Venöz Tromboembolizmin Maliyetleri ve Ekonomik Yükünün Belirlenmesine İlişkin Sistematik Bir Derleme: Farmaekonomik Önleyici Bir Tedavi Olarak Dmah" başlıklı makaledir. Makale Venöz Thromboembolizm, Pulmoner Embolizm, Derin Ven Thrombozunun tedavi maliyetlerinin belirlenmesi ve önleyici antikoagülan bir tedavi olan Düşük Molekül A ğırlıklı Heparin bir sağlık sigortasına veya hastaneye getirdiği ekonomik yükün tespit edilmesi amaçlamaktadır. Çalışma bahsi geçen tedavi seçeneklerinin karşılaştırılması açısından ve özellikle să̆lık sigortalarının bütçesine etkisinin tahmininde büyük öneme sahiptir.

Bu sayımızın ikinci makalesi "Dolar Hegemonyası ve Kripto Para Mühendisliği Üzerine Teknolojik Risk Analizi" başlıklı makaledir. Makalenin yazarı Dr. Ahmet Efe bu çalışmada ABD Dolar senyorajının ne boyutta oluğunu tespit etmek ve bunun kripto paraların yükselişiyle etkilenip etkilenmeyeceğine ilişkin önemli paylaşımlar yapmaktadır.

Sayımızın bir diğer makalesi Öğr. Gör. Gözde UÇAR'ın kaleminden "Risk Sermayesi ve Melek Sermaye Finansman Yönteminin Girişimciliğin Finansmanı Açısından Değerlendirilmesi" başlıklı makaledir. Yazar bu çalışmada risk sermayesi ve melek sermaye finansman yöntemlerini kavram ve işleyiş bakımından incelemektir. Ayrıca, Dünya'da ve Türkiye'de girişimciler tarafindan hangi yöntemin daha fazla kullanıldı̆̆ı ya da ulaşılabilirliği açısından değerlendirmeler yaparak, yöntemlerin farklarını ve benzerliklerini ortaya koymaktadır.

Dr. Öğr. Üyesi Ali YILMAZ, Dr. Öğr. Üyesi Ahmet KAR ve Arş. Gör. Mustafa KAYA'nın kaleme aldığı "Hasta Güçlendirme ve Yaşam Kalitesi İlişkisi" başlıklı makale, hasta güçlendirme ve yaşam kalitesi arasındaki ilişkinin ve hastaların yaşam kalitesini etkileyen faktörlerin belirlenmesi amaçlamaktadır. Bu çalışma hasta güçlendirme ile yaşam kalitesi arasında ilişki olduğu ve hasta güçlendirmenin yaşam kalitesini artırdığını ortaya koyması bakımından önem arz etmektedir.

“Otel Çalışanlarının İş Tanımları Konusundaki Farkındalıkları Üzerine Bir Araştırma" başlıklı makale Oğuz TÜRKAY ve Murat EREN tarafindan kaleme alınmıştır. Makalede otel işgörenlerinin iş tanımların bilme durumlarının çok 
boyutlu bir perspektiften incelemesi amaçlanmaktadır. Çalışma sonuçları otel IKKY yetkilerinin iş tanımlarını netleştirmeleri gerektiği yönündeki bulgusuyla dikkat çekmektedir.

Sayımızın bir diğer makalesi "Kamu Hastanelerinde ve Özel Hastanelerde Yapılan Diş Çevre Analizinin Vizyon ve Misyon Oluşturma İle İlişkisi Hakkında Yönetici Görüşleri (Ankara İlinde Bir Uygulama)" başlıklı makaledir. Dr. Özlem DEMIR ve Prof. Dr. Zekai ÖZTÜRK tarafindan kaleme alınan çalışma Ankara ilinde faaliyette bulunan kamu ve özel hastanelerde yapılan dış çevre analizinin misyon ve vizyon oluşturma ile ilişkisi hakkındaki yönetici görüşlerinin belirlenmesini amaçlamaktadır.

Doç. Dr. Recep YILMAZ ve Rabia BÖLÜKBAŞI'nın hazırladıkları "Faizsiz Finansman Bonosu Sukuk Uygulaması ve Muhasebeleştirilmesi" adlı makale, bir yatırım aracı olan SUKUK"u irdeleyerek muhasebeleştirilmesine dair literatüre katkı să̆lamaktadır.

Sayımızın son makalesi Dr. Öğr. Üyesi Ayhan SERHATERİ ve Fatih Güray KURŞUN tarafindan yazılan "Deneyimsel Pazarlamanın Tüketici Satın Alma Niyeti Üzerine Etkisi: Sakarya İli Örneği" başlıklı makaledir. Makalede yazarlar deneyimsel pazarlamanın tüketici üzerindeki ve tüketicinin satın alma niyeti üzerindeki etkilerinin detaylı olarak açıklamaktadır.

Dergimiz bu sayısı da işletmeciliğin farklı disiplinlerinde değerli bilim insanlarının kıymetli çalışmalarıyla zengin bir içerik sunmaktadır. Dergi politikası olarak bundan sonraki sayılarımızda da işletme bilimine dayal farkh disiplinlerden gelen çalışmaları yayınlamaya özen göstereceğiz. Bu sayımızda göndermiş oldukları makaleler ile dergimize katkı sağlayan tüm yazarlarımıza, dergimize gönderilen makalelerin değerlendirilmesi için kıymetli vakitlerini ayıran saygıdeğer hakemlerimize ve makalelerin dergide yayınlanmaya hazır hale gelmesi için yoğun bir gayret gösteren editör kurulumuz ve dergi sekretaryamıza teşekkürlerimi sunarım. Dergimizin okurlarımı ve bilim insanlarına faydalı olması dileklerimle sonraki sayılarımızda işletmeciliğin güncel çalışmalarını bilim dünyasının hizmetine sunmak için siz değerli bilim insanları ve araştırmacıların katkıların bekliyoruz.
Işletme Bilimi Dergisi

2020

Cilt:8 Sayı:1

Saygılarımızla...

Prof. Dr. Mahmut AKBOLAT

Editör 
İşletme Bilimi Dergisi

2020

Cilt:8 Sayı:1
İÇİNDEKİLER/CONTENTS

Yil (Year) 2020 Cilt (Vol.) 8 Sayı (No) 1

\section{Derleme Makaleleri/Review Articles}

Risk Sermayesi ve Melek Sermaye Finansman Yönteminin Girişimciliğin Finansmani Açisindan Değerlendirilmesi

Evaluation of Risk Capital and Angel Capital Financing Method in Terms of Entrepreneurship

Financing

Öğr. Gör. Gözde UÇAR

Dolar Hegemonyasi Ve Kripto Para Mühendisliği Üzerine Teknolojik Risk Analizi

Technological Risk Analysis on Crypto Currency Engineering and Dollar Hegemony

Dr. Ahmet Efe

\section{Araştırma Makaleleri/Research Articles}

Venöz Tromboembolizmin Maliyetleri ve Ekonomik Yükünün Belirlenmesine Ilişkin

Sistematik Bir Derleme: Farmaekonomik Önleyici Bir Tedavi Olarak Dmah

A Systematic Review of The Determination of Costs And Economic Burden of Venous

Thromboembolism: Lmwh As A Pharmaeconomic Preventive Therapy

Arş. Gör. Gülsüm Şeyma KOCA ve Prof. Dr. Yusuf ÇELIKK

Hasta Güçlendirme ve Yaşam Kalitesi Ilişkisi

The Relationship of Patient Empowerment and Life Quality

Dr. Öğr. Üyesi Ali YILMAZ, Dr. Öğr. Üyesi Ahmet KAR ve Arş. Gör. Mustafa KAYA

Otel Çalișanlarinin Iș Tanimlari Konusundaki Farkindaliklari Üzerine Bir Araștirma

A Research on Awareness of Hotel Employees on Job Description

Ŏ̆uz TÜRKAY ve Murat EREN

Kamu Hastanelerinde ve Özel Hastanelerde Yapilan Diş Çevre Analizinin Vizyon ve Misyon Oluşturma İle İlişkisi Hakkinda Yönetici Görüşleri (Ankara İlinde Bir Uygulama) Administrative Opinionson the Relationship of External Environmental Analysis in Public and Private Hospitals on Vision and Mission Building (An Application in Ankara)

Dr. Özlem DEMIR ve Prof. Dr. Zekai ÖZTÜRK

Faizsiz Finansman Bonosu Sukuk Uygulamasi Ve Muhasebeleştirilmesi

The Application and Accounting of Interest Free Financial Bond SUKUK

Doç. Dr. Recep YILMAZ ve Rabia BÖLÜKBAŞI

Deneyimsel Pazarlamanin Tüketici Satin Alma Niyeti Üzerine Etkisi: Sakarya Ili Örneği

Effect of Experimental Marketing on Consumer Purchase Intention: Sakarya Province Case

$195-226$ Dr. Öğr. Üyesi Ayhan SERHATERİ ve Fatih Güray KURŞUN 


\section{DENEYIMSEL PAZARLAMANIN TÜKETICII SATIN ALMA NIYYETI ÜZERINE ETKİSİ: SAKARYA İLI ÖRNEĞİ}

\author{
Dr. Öğr. Üyesi Ayhan SERHATERI \\ Sakarya Üniversitesi, İşletme Fakültesi, İşletme Bölümü \\ ayhans@sakarya.edu.tr \\ ORCID ID: orcid.org/ 0000-0001-6919-012X \\ Fatih Güray KURŞUN \\ Can Yayınları, İstanbul \\ fatihguraykursun@gmail.com \\ ORCID ID: orcid.org/ 0000-0002-9122-7141
}

Deneyimsel

Pazarlamanin

Tüketici Satın

Alma Niyeti

Üzerine Etkisi

195

\section{ÖZ}

Amaç: Bu çalışmada deneyimsel pazarlamanın tüketici üzerindeki etkisi ve tüketici satın alma niyeti üzerindeki etkilerinin detaylı olarak açıklanması amaçlanmaktadır. Bu amaç doğrultusunda demografik faktörlerin deneyimsel boyutlara etkisini araştırmak ve deneyimsel pazarlamanın tüketicinin satın alma niyetini ne oranda etkilediğini tespit edilmesi hedeflenmiştir.

Yöntem: Bu araştırmada Sakarya şehrinde market alışverişi yapan 400 kişiye anket uygulanmıştır. Anket sonuçları değerlendirilirken, Faktör Analizi, T Testi, Regresyon analizi ve Tek yönlü ANOVA testi uygulanmıştır. Demografik faktörlerin deneyimsel pazarlamaya etkisi ve deneyimsel pazarlamanın boyutlarının satın alma niyetine etkisi olup olmadığı incelenmiştir.

Bulgular: Yapılan regresyon analizi sonucunda deneyimsel pazarlamanın boyutlarının tüketici satın alma niyetine etkisi olduğunu desteklenmiştir.

Sonuç: Deneyimsel pazarlama boyutları tüketici satın alma niyetini pozitif yönde etkilemektedir.

Anahtar Kelimeler: Deneyimsel Pazarlama, Tüketici davranışları, Satın alma tüketici niyeti, Müşteri deneyimi ve Pazarlama deneyimi 
Deneyimsel

Pazarlamanın

Tüketici Satın

Alma Niyeti

Üzerine Etkisi

196

\section{EFFECT OF EXPERIMENTAL MARKETING ON CONSUMER PURCHASE INTENTION: SAKARYA PROVINCE CASE}

\begin{abstract}
Aim: In this study, it is aimed to explain in detail the effects of experiential marketing on consumer and intention to buy.

For this purpose, it is aimed to investigate the effect of demographic factors on experiential dimensions and to determine to what extent experiential marketing affects the consumer's purchase intention.

Methods: In this study, 400 people were employed in the market in Sakarya. When the results of the questionnaire were evaluated, Factor Analysis, T Test, Regression Analysis and One Way ANOVA test were applied. The effect of demographic factors on experiential marketing and whether the dimensions of experiential marketing are influenced by intent to purchase has been examined.
\end{abstract}

Findings: As a result of the regression analysis, it was supported that the dimensions of experiential marketing had an effect on consumer purchasing intention.

Results: Experiential marketing dimensions positively affect consumer intention to purchase.

Keywords: Experiential Marketing, Consumer Behavior, Consumer intention to buy, Costumer Experience, Marketing Experience

\title{
I. GíRiş
}

Rekabet avantajı sağlamak için değişime ayak uydurma zorunluluğu her geçen gün artan şiddetiyle işletmeler üzerinde baskı oluşturmaya devam etmektedir. Teknoloji, üretim anlayışındaki değişikliklere uyum için işletmeler tedbir almak durumundadırlar. Tüketiciler, birbirinin tıpatıp aynısı olan binlerce ürün arasından tercih yaparken, ürün hakkında bilgi edinmekte ve karşılaştırma yapmaktadır. $\mathrm{Bu}$ süreçte evrilen istek ve ihtiyaçlara göre şekillenen satın alma davranışında deneyim kavramı öne çıkmaya başlamıştır. Müşteri bağlılığ yaratmak suretiyle rekabet avantajı elde etmek isteyen işletmeler deneyimsel pazarlama kapsamındaki çalışmalara yönelmiştir.

Geleneksel tüketici profilinden hızla uzaklaşan yeni grup tüketiciler, ürün veya hizmeti araştırmakta, fiyat karşılaştırması yapmakta, kendilerine göre en yüksek faydayı sağladığını düşündükleri ürünü veya 
hizmeti tercih etmektedirler. $\mathrm{Bu}$ durumda işletmelerin tüketici istek ve ihtiyaçlarına uygun ürün veya hizmeti sunması için satınalma davranışına yönelten sebepleri anlama zorunluluğu ortaya çıkmaktadır.

Gelişen teknoloji ve artan ürün yelpazesi sayesinde günümüzde tüketici profil yapısında birçok değişiklik meydana gelmiştir. Değişen tüketim yapısıyla tüketiciler artık sadece faydacı veya hazsal seçim yapmak yerine isteklerinin tamaminı karşılayacak tek bir ürün aramaktadır. Tüketici satın alma niyetinde meydana gelen bu değişik, tüketicileri ikna edebilmek için deneyimsel pazarlamanın avantajlarını kullanmayı zorunlu kılmaktadır.

Dünyada meydana gelen küreselleşme ve artan rekabet koşulları müşteri tutum ve isteklerini firmalar için önemli bir hale getirmiştir. Avantaj sağlamak isteyen işletmeler yeni pazarlama uygulamalarını geliştirmeye çalışmışlardır. Bundan dolayı ürün veya hizmettin özelliklerinden çok tüketici deneyimi yaşatmaya odaklanmaya başlamıştır (Ekici, 2012:32). Çalışma 3 bölüm halinde tasarlanmıştır. Birinci bölümde deneyimsel pazarlama kavramı ve deneyim kavramı üzerinde durulmuştur. İkinci bölümde Tüketici davranışları ve satın alma niyeti üzerinde durulmuştur. Üçüncü bölümde ise araştırma sonuçlarına yer verilmiştir.

\section{Literatür İncelemesi}

\subsection{Deneyim Kavramı}

Deneyim; duygulardan yola çıkılarak etraftaki çevrenin, insan ve hayvan davranışlarının ve düşüncelerin tanımlanmasını sağlayan ve yaşanılan olaylardan elde edilen bilgi ve becerilerin tamamı olarak tanımlanmıştır (Bostancı, 2007:17). Kişilerin yaşamlarında yaşadıkları, yapmakta oldukları veya karşılıklı ilişki halinde oldukları ve sürekli bir şekilde devam eden tecrübelerdir. Deneyimlerin özellikleri, kişilerin algılamaları zamanla değişmesi, yaşanılan duyularında odaklanma, ilgi ve konsantrasyon fazla olması, kişilerin için duygusal karşılığı olması, yaşanılan aşamalar kişiler için eşsiz olması, elde edilen deneyim karşılıklı iki tarafın birbirine etkisi üzerine oluşması, kişilerin duruma bilinçli bir müdahalesi vardır, deneyimin ulaşılmak istenen bir amacı olması, kişinin direnci, emeği ve kapasitesiyle ilişkili olmasıdır (Boswijk et al., 2005).

\subsection{Deneyim Ekonomisi}

Gelişen üretim anlayışıyla birlikte artık insan hayatında olan teknolojik aletler bile birbirlerine benzemeye başlamıştır. İşletmeler hayatta kalmak
Deneyimsel

Pazarlamanın

Tüketici Satın

Alma Niyeti

Üzerine Etkisi

197

\section{.

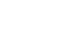


Deneyimsel

Pazarlamanin

Tüketici Satın

Alma Niyeti

Üzerine Etkisi

198 ve onlara bağlı müşterileri kaybetmemek için ürünlerini farklılaştırmak yoluna gitmek zorundadır(Pine ve Gilmore, 1998:20). Deneyim ekonomisi kavramı ilk kez B. Joseph Pine II ve James H. Gilmore tarafından kullanılmıştır. Bir ürünün ekonomik olarak değer biçilebilmesi için deneyimler, hizmetler, ürünler ve mallar olarak 4 evreden geçtĭgi belirtilmiştir(Pine ve Gilmore, 1999:6).

\subsection{Deneyimsel Pazarlama Özellikleri}

Deneyim ekonomisi kavramıyla birlikte hizmet ve ürün sektörlerinde üretim anlayışı müşteri deneyim ve istekleri üzerine hazırlanmaya başlanmıştır. Müşteri deneyimlerini önemseyen işletmeler bu durumun işletme karını artırdığını ve rekabet avantajı kazandırdığını ifade etmektedirler (Poulsson ve Kale, 2004:45). Deneyimsel pazarlamanın yaklaşımları geleneksel pazarlama anlayışından farklıdır. İşletmenin veya üretim anlayışına odaklanmak yerine müşterilerin bilişsel, duyusal, davranışsal, duygusal ve ilişkisel motivasyonlar üzerine odaklanmaktadır. Tüketici deneyim ve ihtiyaçlarını anlayabilmek için kalitatif ve kantitatif yöntemler kullanılmaktadır (Schmitt, 2004:60).

\subsection{Deneyimsel Boyutlar}

Deneyimsel pazarlama tüketicinin beş duyu organına hitap etmekte ve tüketicinin yaşayabileceği beş farklı deneyimden oluşmaktadır. Yaşam şekline ve davranışlara dayanan deneyimler davranışsal, duygu ve ruh haline dayanan deneyimler duygusal, Gelişime ve bilişsel özelliklere dayanan deneyimler düşünsel, sosyal çevre ve kültüre dayanan deneyimler ilişkiseldir, duyu organlarına dayanan deneyimler duyusaldır.

Deneyimsel pazarlamanın beş ayrı deneyime dayandığından söz edilmiştir. Bunlar Schmitt tarafından "Stratejik Deneyimsel Modüller" olarak adlandırılmış ve sınıflandırılmıştır (Schmitt, 1999a); Duygusal deneyim, Duyusal deneyim, Davranışsal deneyim, Düşünsel deneyim, İlişkisel deneyim olarak sınıflandırılmaktadır. Deneyim Boyutları; beş duyu organlarıyla ilişkilendirilmiştir. Bunlar; Görme, işitme, dokunma, tatma ve koklamadır.

Duyusal Deneyim: Duyular dokunma, tatma, görme, koklama ve duymadan oluşmaktadır. Duyusal deneyimleri dizayn eden şirketler tüketicinin zihninde markayı konumlandırmaktadırlar. $\mathrm{Bu}$ marka dizaynlarının sonucunda üretilen marka imajı sadece ürünün özellikleriyle veya kullanıldığı alanla sınırlı kalmaz, bunun ötesine geçerek ürün tüketicinin zihninde farklı duyusal özellikler olarak canlanır ve duygusal 
olarak ürüne karşı bağlılığı arttırılır (Schmitt, 1999b: 109-111).

Duygusal Deneyim: Tüketici zihninde işletme ve markayla ilgili duyguları harekete geçirecek deneyimler oluşturulmasıdır. Tüketicilerin bir ürünle bir duyguyu en çok bağdaştırdığı veya duygularının harekete geçtiği en önemli yer tüketimdir (Schmitt, 1999b: 129).

Düşünsel Deneyim: Tüketicinin düşünceleri etkilemek için düşünsel deneyimin tüketici de ortaya çıkması için yapılan, düşünsel pazarlamanın amacı hedef kitlenin şirketin ürettiği ürünler veya hizmetler hakkında ayrıntılı düşünmesini sağlamak ve zihninde önemli bir yer edinmesini sağlayacak düşünceleri düşünmesini sağlamaktır (Schmitt, 1999b:138).

Davranışsal Deneyim: Hedeflenen tüketici kitlesinin yaşam tarzının incelenerek çeşitli yollar sunularak, tüketicilere farkı bir yaşam seçeneği sunulmaya çalışılmaktadır. Temel olarak farklı ürün ve hizmetlerin kullanılarak tüketicinin yaşam tarzında değişiklik meydana getirmek ve onları farklı deneyimler önererek hayat tarzlarını değiştirmektir. Bu davranışsal deneyimler duygusal, duyusal ve düşünsel yönlerden tüketiciyi harekete geçirecek davranışsal deneyimler olarak tanımlanmıştır. (Schmitt, 1999b: 154-160).

İlişkisel Pazarlama: Tüketiciler kendi düşüncelerine ve duygularına uygun markalar bularak kendileriyle ilişkilendirirler. İşletmeler, tüketicilerine doğru deneyimi yaşatabilmek ve ürünlerini satabilmek için hedef kitlelerini iyi tanımalı ve ürettikleri ürün veya imajlarını buna göre tasarlamaları gerekmektedir.

İlişkisel deneyim kurmaya çalışan bütün işletmelerin temel amacı tüketiciyle ürün arasında bağ kurmak ve özleştirmeye çalışmaktadır. Deneyimler referans gruplardan, kültürel çevreden, kişilerin yakın ilişkilerinden, dahil oldukları grup ve sınıflardan elde edilmektedir (Kotler et al., 1998:181-199).

\section{Deneyimsel Pazarlamanin Faydaları}

İşletmeler tarafından uygulanan deneyimsel pazarlama çalışmaları işletmelere, farklılaştırma sonucu işletme kimliği özelleşmesi, Tüketici isteklerini yönlendirilmesi, Kişiye özel hizmet ve kişiselleştirilmiş hizmet sağlaması, Kar oranlarını ve satışları yükseltmesi, Ürün niteliğinin nasıl olması gerektiğiyle ilgili tüketici istekleri hakkında bilgiler sunması, tüketici bağlılığını arttırması, işletmenin özelliklerini ortaya çıkararak tüketiciyle iletişim sağlaması gibi faydaları sağlamaktadır(Edvardsson et al., 2005:150).

\subsection{Deneyimsel Pazarlama Yönetimi}

Deneyimsel

Pazarlamanin

Tüketici Satın

Alma Niyeti

Üzerine Etkisi

199 
Deneyimsel

Pazarlamanın

Tüketici Satın

Alma Niyeti

Üzerine Etkisi

200

Ürün çeşitliliğinin artması, ürünlerin değerlendirme ve satın alma kriterinin her geçen gün değiştiği günümüzde tüketici kitlesinin ürünleri ve markayı hatırlaması gittikçe zorlanmaktadır. Bunun sonucu olarak deneyimsel pazarlama yönetimi zorunlu hale gelmektedir. Tüketici kitlesinin marka, ürün ve hizmetlerle bağ oluşturmak isteyen her işletme tüketicinin neyi aradığını, ürün, hizmet ve markayla iletişim noktalarını bilmek ve buna göre hareket etmek zorundadır. Deneyimsel pazarlama üç aşamadan oluşmaktadır (Schmitt, 2003: 24). Analiz, uygulama ve strateji olarak üç ayrı aşaması vardır. Analiz kısmında; tüketici analizi başlı̆̆ altında rakiplerin, tüketiciyle bir araya gelinen noktaların, hedef kitlenin, deneyimsel mekanların ve araştırma çeşitlerinin belirlenmesi gerçekleştirilmektedir. Uygulama kısmı, marka deneyimi oluşturulması ve sürekli gelişimden(inovasyon) oluşmaktadır. İletişimde yaşanan deneyimler, markanın görüntüsü ve hissettirdiği duygular, ürünlerin deneyimi marka deneyimi oluşturulmasının kapsamındadır. Strateji aşaması, deneyimsel alanların oluşturulması ve tüketici etkileşiminin oluşturulmasından oluşur.

\subsection{Deneyimsel Pazarlama Araçları}

İletişim araçları promosyon ürünlerden, insanlardan, internet sitelerinden, çevre düzenlemelerinden vb. araçlardan oluşmaktadır. Bu araçlar sayesinde tüketiciyle işletme arasındaki bağ güçlenmekte ve tüketicilere ürün ve hizmetleri daha ayrıntılı tanitma firsatı elde edilmektedir (Doğan, 2006: 41). İnternet teknolojisinde meydana gelen gelişmeler sonucunda sosyal platformlar kullanılarak yapılan ve mobil pazarlama araçları kullanılarak günümüzde deneyimsel pazarlamanın kullanılması noktasında etkili olmaktadır (Schmitt, 1999: 63).

\subsection{Deneyimsel Pazarlama Uygulama Alanlan}

İşletmelerin nerede ve ne zaman organizasyon yapacaklarına karar vermesi zor bir süreçtir. Bu konuyla ilgili çeşitli modeller olup konum hiyerarşi modeliyle konuyla ilgili yol haritası ortaya konmaya çalışılmıştır. Modele göre işletmeler sadece beş farklı mekân seçeneğiyle deneyimsel pazarlamanın avantajlarını kullanabileceği belirtilmiştir. Bu mekanlar: deneyim merkezleri, outletler, ticari merkezler, merkezi mekanlardaki faaliyetlerde ve dünya pazarları olarak sıralanmaktadır (Gilmore ve Pine, 2002:7). Deneyim yerleri sadece fiziksel mekanlarla kısttl değildir. İşletmeler günümüzde teknolojiyi de kullanarak sanal ortamlarda da yer almaktadırlar (Gilmore ve Pine, 2002 :9). 


\subsection{Deneyimsel Pazarlama Yönetimi Aşamaları}

Deneyimsel pazarlama yönetiminde temel amaç işletmeler için yeni stratejiler denemek ve işletmeler için uygulamaktır. Tüketiciyle çeşitli akademik araştırmalar yaparak sürekli bir şekilde gözlem, anket ve mülakat çalışmaları yapılması gerekmektedir. Küreselleşme sonucu tüketici kitlesinin fikir, istek ve ihtiyaçları sürekli değişmektedir. Çalışmalar sonucunda elde edilen veriler sınıflandırılmalı, çeşitli stratejik deneyim metotları oluşturulmalı, sınıflandırılmalı ve deneyim haritası oluşturulmalıdır. Deneyim çeşitleri belirlendikten sonra yararlı ve yararsız deneyimler belirlenerek mali açıdan avantaj elde edilebilir.

\subsection{Müş̧teri Deneyimi Yönetimi}

Tüketicinin istek, arzu ve ihtiyaçları gözetilerek işletmenin ürün ve hizmetlerinin tamaminin deneyimlerinin profesyonel olarak planlanmasıdır (Schmitt, 2003a:25). İşletmelerin sadece tüketiciler için deneyim sağlayacak organizasyonlar ve alanlar oluşturması yetmez. Deneyim yaratmak için oluşturulmuş organizasyonların profesyoneller tarafından hazırlanmış olması, buna dair profesyonel bir bakış açısı gerekmekte ve işleri profesyonel bir şekilde düzenleyecek bir yönetime ihtiyaç duyulmaktadır. Bunun temel sebepleri arasında profesyonel bir yaklaşım sergilemeyen işletmeler hedef kitlelerini doğru seçememektedirler.

\subsection{Tüketici Kavramı}

Tüketici, işletmelerin ürettim anlayışlarının sonucunda ortaya çıkan nihai ürün veya hizmeti satın almaya gönüllü kişiler veya kurumlardır (Odabaşı ve Barış, 2010:20). Başka bir bakış açısıyla kendi istek ve ihtiyaçlarını tatmin etmek için ürün ve hizmetlerin kişilerce tüketilmesidir. Tüketici davranışları, bir kişinin veya bir grubun ihtiyaç, istek ve arzularının sağlanması amacıyla arzu ettikleri ürün, hizmet ve diğer hizmetleri kişilerin önceki deneyimleri kullanılarak, organize bir süreç olarak tanımlanmıştır (Solomon, 2007:7).

\subsection{Tüketicinin Satın Alma Kararı Süreci}

Tüketicilerin satın alma kararları iki şekilde sınıflandırılmıştır. Bunlar; "otomatik satın alma" "karar vermeli satın alma" olarak iki bölüme ayrılmıştır. Otomatik satın alma eylemi bireylerin vakit kaybetmeden ihtiyaçlarını karşılayabilecek ürün ve hizmetleri satın alması olayıdır. Kişiler bu satın alma çeşidinde ürün ve hizmetlerle ilgili herhangi bir araştırma veya karşılaştırma yapmazlar. Karar vererek satın aldıkları durumlarda kişiler almak istedikleri ürün ve hizmetlerle ilgili gerekli
Deneyimsel

Pazarlamanin

Tüketici Satın

Alma Niyeti

Üzerine Etkisi

201 
Deneyimsel

Pazarlamanın

Tüketici Satın

Alma Niyeti

Üzerine Etkisi

202 araştırma, karşılaştırmaları yaparak ve buna zaman harcayarak satın alma işlemlerini gerçekleştirirler (Karafakioğlu, 2008:104-105).

\subsection{Tüketicilerin Satın Alma Davranışlarını Etkileyen Faktörler}

Tüketicilerin karar verme aşamaları karmaşık kompleks bir süreçtir. Tüketicilerin davranışlarını etkisi altında bırakan belirli psikolojik faktörler bulunmaktadır. Davranışlara etkide bulunan psikolojik faktörler; motivasyon, algılama, öğrenme, tutum ve kişilik olarak sıralanmaktadır. Sosyal faktörler: kültür, alt kültür, sosyal sınıf, referans gruplar, roller ve aileden oluşmaktadır. Tüketiciler sadece kendi istek, arzu ve ihtiyaçları için alışveriş yapmazlar, aynı zamanda sosyal olarak etkileşimde bulundukları insanlar için de belirli ürün ve hizmetleri satın alırlar (Wilson, 1998). Kişisel Faktörler, kişilerin, hayata bakış açılarını ve satın alma davranışlarını etkileyen, kişinin sahip olduğu demografik faktörler, durumsal faktörler ve yaşam biçimini oluşturan davranışlar bütünüdür. Yaş, cinsiyet, meslek ve ekonomik durum kişisel faktörleri ifade etmektedir.

\subsection{Hipotez Geliştirme}

Rekabet ve üretim anlayışında yaşanan gelişmeler sonucunda üretilen ürünlerin müşteri tarafından fark edilmesi ve işletmeler rekabet avantajı elde etmek amaciyla deneyimsel pazarlamanın avantajlarından yararlanmaya başlamışlardır. Deneyimsel pazarlamanın avantajlarından yararlanılarak tüketici satın alma niyetine değiştirmeye çalışmışlardır. Bu bağlamda bu araştırmanın amacı deneyimsel pazarlamanın tüketici satın alma niyetine etkisi olup olmadığını belirlemektir. Çalışmanın modeli Çiçek (2015) tarafından geliştirilen modelden uyarlanmıştır. Literatüre dayanılarak oluşturulmuş araştırma modeli şekilde verilmiştir.

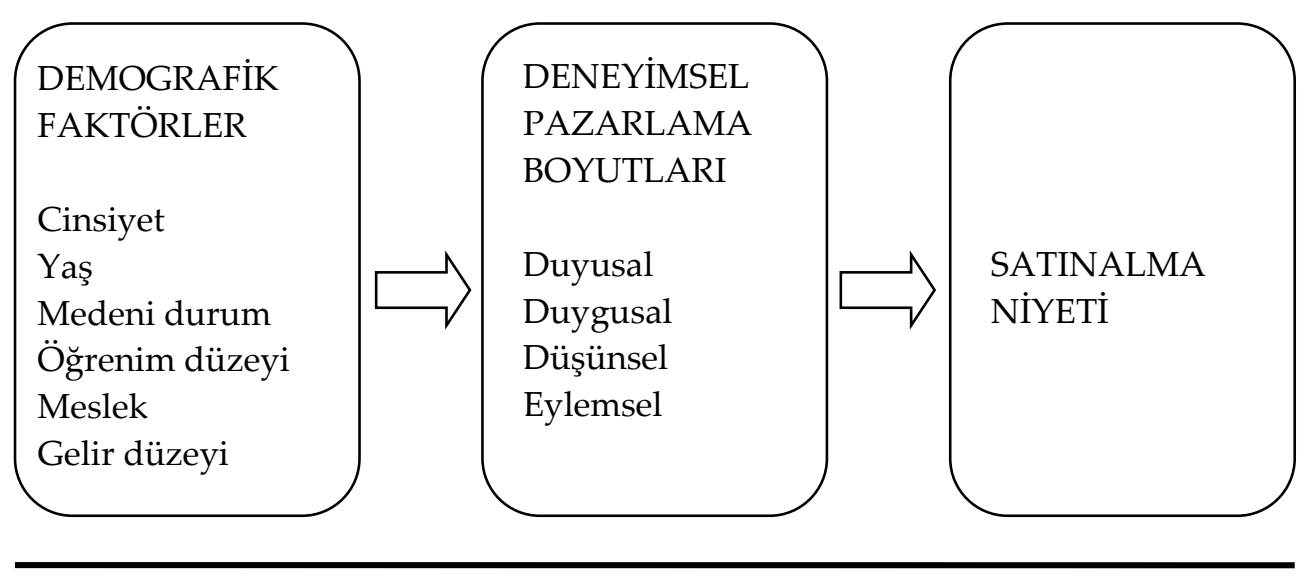


Şekil 1.Deneyimsel Pazarlama Modeli (Çiçek,2015)

Çalışmanın hipotezleri: Modeldeki değişkenlerin literatürdeki yapılan araştırmalar sonucunda ilişkiler temelinde geliştirilmiştir. Araştırmanın amaçları doğrultusunda aşağıda yer alan hipotezler oluşturulmuştur.

H1: Deneyimsel pazarlamanın deneyim boyutları itibariyle cinsiyete göre farklılık göstermektedir.

H2: Deneyimsel pazarlamanın deneyim boyutları itibariyle yaşa göre farkl1lık göstermektedir.

H3: Deneyimsel pazarlamanın deneyim boyutları itibariyle medeni duruma göre farklılık göstermektedir.

H4: Deneyimsel pazarlamanın deneyim boyutları itibariyle öğrenim düzeyi göre farklılık göstermektedir.

H5: Deneyimsel pazarlamanın deneyim boyutları itibariyle meslek gruplarına göre farklılık göstermektedir.

H6: Deneyimsel pazarlamanın deneyim boyutları itibariyle gelir düzeylerine göre farklılık göstermektedir.

H7: Deneyimsel pazarlama boyutlarının, satın alma niyeti üzerinde istatiksel olarak pozitif anlamlı bir etkisi vardır.

H7a: Deneyimsel pazarlamanın duyusal boyutunun tüketici satın alma niyeti üzerine istatistiksel olarak anlamlı bir etkisi vardır.

H7b: Deneyimsel pazarlamanın duygusal boyutunun tüketici satın alma niyeti üzerine istatistiksel olarak anlamlı bir etkisi vardır.

H7c: Deneyimsel pazarlamanın düşünsel boyutunun tüketici satın alma niyeti üzerine istatistiksel olarak anlamlı bir etkisi vardır.

H7d: Deneyimsel pazarlamanın eylemsel boyutunun tüketici satın alma niyeti üzerine istatistiksel olarak anlamlı bir etkisi vardır.

\section{Yöntem}

\subsection{Kullanılan Ölçekler}

Araştırmada kullanılan deneyim boyutları olan duyusal, duygusal, eylemsel ve düşünsel boyutları ölçen sorular Brakus, ve arkadaşalarının (2009) çalışmasından, demografik değişkenler ve satın alma niyetini ölçen sorular Saygılı (2014)'ın çalışmasından uyarlanmıştır. Bu iki çalışma temel
Deneyimsel

Pazarlamanin

Tüketici Satın

Alma Niyeti

Üzerine Etkisi

203 
Deneyimsel

Pazarlamanın

Tüketici Satın

Alma Niyeti

Üzerine Etkisi

204 alınmasıyla birlikte bu çalışmalara kaynak olan önceki çalışmalardan da yararlanılmıştır (Dodds et al., 1991; Sirohi et al., 1998; Devaraj et al., 2002; To et al., 2007, Topaloğlu, 2009).

\section{2. Örnekleme ve Veri Toplama}

Araştırma evreni, ulaşılmak istenen amaca ve probleme daha kolay ulaşılması bakımından Sakarya ili olarak belirlenmiştir. Araştırmanın öneminin daha iyi anlaşılabilmesi için 18 yaş üzeri, geliri 1600 TL'nin üzerinde ve Sakarya ilindeki saat 3- 5 arasında marketlerden alışveriş yapmış kullanıcılar evren olarak seçilmiştir. Araştırma evrenin tamamına ulaşmanın imkânsızlığı, zaman ve maliyet kısıtları göz önünde bulundurulduğunda, Basit tesadüfi örneklemede evreni oluşturan her elemanın örneğe girme şansı eşittir. Dolayısıyla hesaplamalarda da her elemana verilecek ağırlık aynıdır (İslamoğlu, 2003: 141). Çalışmaya katacağ1 avantajlar, maliyet ve zaman faktörleri değerlendirip örneklem yöntemlerinden Basit tesadüfü örnekleme yöntemi kullanılmıştır.

Araştırmanın örneklem büyüklügüunün belirlenmesinde, çok değişkenli istatistiksel analiz yöntemi olan faktör analizi göz önüne alınmıştır. Bu çerçevede literatürde örneklem boyutuyla ile ilgili bir standart bulunmamasına rağmen faktör analizinde tercih edilen faktör analizine giren değişken sayısının en az 10 katı kadar veya daha fazla olmalıdır (Altunışık vd., 2007:128). Buradan yola çıkarak ve farklı örneklem büyüklüklerinde Cohen ve arkadaşları (2000) 'nın ortaya koyduğu standart dikkate alınarak 383 olarak belirlenmiştir. Bu bağlamda 400 deneğe ulaşılmış ve istatistiksel analizler açısından sahip olunan örneklem büyüklügünün yeterli olduğu düşünülmüştür.

Verileri toplayabilmek için, veri toplama yöntemi olarak anket kullanılmıştır. Örneklemi oluşturan her bireyin aynı soru setine cevap verebilmesine olanak tanıdığı için, fazla sayıda kişiye ulaşılmasını kolaylaştırdığ 1 ve ideal bir veri toplama aracı olduğu için anket yöntemi tercih edilmiştir (Altunışık vd., 2010: 78). Düzenlenen anketler yüz yüze görüşme yoluyla uygulanmıştır.

\section{Analiz ve Bulgular}

Araştırmada ölçeklerin faktör yapısını test etmek için, temel bileşenler yöntemi ve varimax rotasyonu kullanılarak, keşfedici faktör analizi yapılmıştır. $\mathrm{H} 1$ ve $\mathrm{H} 3$ hiptezi için T testi, $\mathrm{H} 2, \mathrm{H} 4$, H5 ve $\mathrm{H} 6$ için Anova testi, $\mathrm{H7}$ ve alt hipotezler için basit regresyon ve çoklu regresyon kullanılarak analiz edilmiştir. Demografik bilgiler, en sık alışveriş yapılan 
market, en sık tüketilen ürün grubu, ürün gruplarında en çok tercih edilen marka, market tercihi ve alışveriş sıklığı gibi değişkenlere yönelik frekans dağılımları tespit edilmiştir.

Çalışma kapsamında yer alan Sakarya ilinde marketlerden alışveriş yapmış, 400 kullanıcıya ait demografik özellikler Tablo 1'de sunulmuştur.
Deneyimsel

Pazarlamanin

Tüketici Satın

Alma Niyeti

Üzerine Etkisi

Tablo1.

Demografik Bulgular

\begin{tabular}{|c|c|c|c|}
\hline Özellikler & Seçenekler & Frekans & $\%$ \\
\hline \multirow{2}{*}{ Cinsiyet } & Kadın & 235 & 58,8 \\
\hline & Erkek & 165 & 41,2 \\
\hline \multirow{2}{*}{ Medeni durum } & Bekâr & 319 & 79,8 \\
\hline & Evli & 81 & 20,2 \\
\hline \multirow{6}{*}{ Eğitim durumu } & İlköğretim & 7 & 1,8 \\
\hline & Lise & 44 & 11 \\
\hline & Önlisans & 37 & 9,3 \\
\hline & Lisans & 218 & 54,5 \\
\hline & Yüksek Lisans & 89 & 22,3 \\
\hline & Doktora & 5 & 1,3 \\
\hline \multirow{8}{*}{ Yaş } & $18-23$ & 112 & 28 \\
\hline & $24-29$ & 160 & 40 \\
\hline & $30-35$ & 76 & 19 \\
\hline & $36-41$ & 34 & 8,5 \\
\hline & $42-47$ & 10 & 2,5 \\
\hline & $48-53$ & 5 & 1,3 \\
\hline & $54-59$ & 2 & 0,5 \\
\hline & 60 ve Üzeri & 1 & 0,3 \\
\hline \multirow{7}{*}{ Aylık gelir } & $1600-2000$ & 170 & 42,5 \\
\hline & $2001-2500$ & 43 & 10,8 \\
\hline & $2501-3000$ & 56 & 14 \\
\hline & $3001-3500$ & 30 & 7,5 \\
\hline & $3501-4000$ & 22 & 5,5 \\
\hline & $4001-4500$ & 24 & 6 \\
\hline & 4501 ve Üzeri & 55 & 13,8 \\
\hline \multirow{6}{*}{ Meslek } & İşçi & 54 & 13,5 \\
\hline & Emekli & 2 & 0,5 \\
\hline & Ev Hanımı & 12 & 3 \\
\hline & Akademisyen & 25 & 6,3 \\
\hline & Memur & 49 & 12,3 \\
\hline & Öğrenci & 138 & 34,5 \\
\hline
\end{tabular}


Deneyimsel

Pazarlamanın

Tüketici Satın

Alma Niyeti

Üzerine Etkisi

206

\begin{tabular}{llc}
\hline Serbest Meslek & 13 & 3,3 \\
Esnaf & 18 & 4,5 \\
Diğer & 89 & 22,3 \\
\hline
\end{tabular}

Araştırmada, tüketiciler tarafından en sık alışveriş yaptığı market sorulmuştur. Tablo 2'de belirtilen seçenekler ile sorulmuş işaretlemeleri istenmiştir. Katılımcıların en sık tercih ettikleri marketlere bakıldığında, Katılımcılar arasında en çok Migros \%32,5'le tercih edilmekte ve ondan sonra $\% 28,8$ le Bim ve $\% 11,0$ 'la Şok tercih edilmektedir. Migros, Bim ve Şok en çok tercih edilen 3 markettir ve katılımcıların \%72,3'ü tarafından tercih edilmektedir.

Tablo2.

En Sık Alışveriş Yapılan Market

\begin{tabular}{ccc}
\hline Seçenekler & Frekans & Yüzde \\
\hline Migros & 130 & 32,5 \\
Şok & 44 & 11 \\
Bim & 115 & 28,8 \\
Hakmar & 4 & 2,8 \\
Geltat & 11 & 2,3 \\
Essen & 9 & 2,8 \\
Özpaş & 11 & 1,3 \\
File & 5 & 1,3 \\
Diğer & 70 & 17,5 \\
\hline
\end{tabular}

\subsection{Faktör Analizi}

Kaiser-Meyer-Olkin (KMO) testi, faktör analizi yapmak için örneklem sayısının yeterli olup olmadığını, Bartlett küresellik testi ise faktör analizine uygunluğunu değerlendirmek amaciyla KMO ve Bartlett Testi yapılmıştır. Faktör analizinin uygulanabilmesi için Bartlett Testi sonucunun değişkenler arasında faktör analizi yapılabilecek güçte bir ilişki olup olmadığını göstermektedir (İslamoğlu, 2014:402). Verilere faktör analizi yapılmadan önce, verilerin anlamlı çıkması $(p<0,05)$ istenir (İslamoğlu, 2014:402).

KMO ve Bartlett testlerinin sonuçlarının yer aldığı Tablo 3 incelendiğinde $\mathrm{KMO}$ testindeki 0.819 değeri örneklem büyüklüğünün faktör analizi yapabilmek için yeterli olduğunu gösterirken, Bartlett testinin sonucu da 1577,505 ve $\mathrm{p}<0,001$ güven seviyesinde anlaml 
bulunmuştur. Dolayısıyla verilerin faktör analizine uygun olduğu sonucuna varılabilmektedir.

KMO ve Bartlett testlerinin sonuçlarının yer aldığı Tablo 4 incelendiğinde $\mathrm{KMO}$ testindeki 0.777 değeri örneklem büyüklügüünün yeterli olduğunu gösterirken, Bartlett testinin sonucu da 1063,847 ve $\mathrm{p}<0,001$ güven seviyesinde anlamlı bulunmuştur. Dolayısıyla verilerin faktör analizine uygun olduğu sonucuna varılabilmektedir.

Deneyim ölçeğinde yer alan ifadelerin faktör analizine uygunluğu anlaşıldıktan sonra bu ifadelerin toplanacağı boyutları ve bu boyutların sayısını görebilmek amacıyla faktör analizi yapılmıştır. Analiz sonucunda ifadelerin 3 faktör altında toplandığı gözlenmiş olup, faktörler, her bir ifadenin faktör yükleri ve açıklanan varyans yüzdeleri Tablo 5 'te verilmiştir.

Satın alma ölçeğinde yer alan ifadelerin faktör analizine uygunluğu anlaşıldıktan sonra bu ifadelerin toplanacağı boyutları ve bu boyutların sayısını görebilmek amacıyla faktör analizi yapılmıştır. Analiz sonucunda ifadelerin 1 faktör altında toplandiğ 1 gözlenmiş olup, faktör, her bir ifadenin faktör yükleri ve açklanan varyans yüzdeleri Tablo 6'da verilmiştir.

Yapılan faktör analizi sonucunda 1 ifade diğer faktörlerden yeterli şekilde ayrışmadığı için ölçekten çıkarılmıştır. Oluşan faktör yapılarını adlandırmak için, her bir faktörün altında yer alan değişkenlerin içerikleri dikkate alınmıştır. Buna göre ilk faktöründe altında toplanan değerler incelendiğinde kişilerin deneyimleri sonucundaki eylemleri içerdiğinden ilk faktör "eylemsel boyut" olarak adlandırılmıştır. İkinci faktör altında toplananlar incelendiğinde duyusal deneyimle ilgili sorular içerdiğinden "Duyusal Boyut" olarak adlandırılmıştır. Üçüncü Faktör altında toplanan değişkenler incelendiğinde Düşünceyi ve duygusal durumu ölçen sorulardan oluştuğu için "Düşünsel Boyut" olarak adlandırılmıştır.

Tek faktörün altında toplanan değerler incelendiğinde, hepsinin satın alma davranışı ve niyeti ile ilgili sorular olduğu dikkate alınarak faktör "Satın Alma Niyeti" olarak adlandırılmıştır.

Tablo 7'de yer alan veriler değerlendirildiğinde, uygulanan faktör analizi sonucunda öz değeri birin üstünde olan üç adet faktörün meydana geldiği bulunmuştur. $\mathrm{Bu}$ faktörlerden ilkinin toplam varyansın $\% 23,680^{\prime}$ ını, ikinci faktör $\% 22,408^{\prime}$ ini, üçüncü faktörün $\% 16,468^{\prime}$ 'n açıklamaktadır. Bu üç faktör birlikte ise toplam varyansın \%62,556'sini
Deneyimsel Pazarlamanin Tüketici Satın Alma Niyeti Üzerine Etkisi 
Deneyimsel

Pazarlamanın

Tüketici Satın

Alma Niyeti

Üzerine Etkisi

208

açıklamaktadır. Elde ettiğimiz değer arzu edilen değerin (\%60) üzerindedir. (Kurtuluş, 2010:190).

Tablo 8 'de yer alan veri değerlendirildiğinde, uygulanan faktör analizi sonucunda öz değeri birin üstünde olan 1 adet faktörün meydana geldiği bulunmuştur. Bu faktör ise toplam varyansın \%64,981'ini açılamaktadır. Elde ettiğimiz değer arzu edilen değerin (\%60) üzerindedir. (Kurtuluş, 2010:190).

Tablo3.

Deneyim Ölçeği İçin KMO ve Bartlett Testi

\begin{tabular}{ccc}
\hline \multicolumn{2}{c}{ Kaiser- Meyer- Olkin Measure Örneklem Uyum } &, 819 \\
\hline Testi & 1577,505 \\
Bartlett & Yaklaşık Ki-kare & 55 \\
Testi & df &, 000 \\
& Sig. & \\
\hline
\end{tabular}

Tablo4.

Satın alma Ölçeği İçin KMO ve Bartlett Testi

\begin{tabular}{ccc}
\hline \multicolumn{2}{c}{ Kaiser- Meyer- Olkin Measure Örneklem Uyum } &, 777 \\
\hline Testi & 1063,847 \\
Bartlett & Yaklaşık Ki-kare & 10 \\
Testi & df &, 000 \\
\hline
\end{tabular}

Tablo5.

Deneyim Ölçeği İçin Açıklayıcı Faktör Analizi Sonuçları (Temel Bileşenler Analizi, Varimax Döndürme, $N=400$ )

\begin{tabular}{lcc}
\hline \multicolumn{1}{c}{ İfadeler } & $\begin{array}{c}\text { Faktör } \\
\text { Yükleri }\end{array}$ & $\begin{array}{c}\text { Açıklanan } \\
\text { Varyans \% }\end{array}$ \\
\hline \multicolumn{1}{c}{$\begin{array}{l}\text { Eylemsel Boyut } \\
\text { Bu markettin ürünlerini kullanmak beni aynı davranışı }\end{array}$} & $\mathbf{0 , 8 1 3}$ & \\
tekrar etmeye teşvik eder. & 0,712 & \\
$\begin{array}{l}\text { Bu markettin ürünleri bana tümüyle bir deneyim yaşatır. } \\
\text { Bu markettin ürünlerinin benim gözümde duygusal bir }\end{array}$ & $\mathbf{0 , 6 7 7}$ & \\
$\begin{array}{l}\text { anlamı vardır. } \\
\text { Bu markettin ürünlerini kullanmak beni aynı davranışı } \\
\text { tekrar etmeye teşvik etmez. }\end{array}$ & 0,553 & \\
\hline
\end{tabular}


Tablo5. Devamı

\begin{tabular}{|c|c|c|}
\hline İfadeler & $\begin{array}{l}\text { Faktör } \\
\text { Yükleri }\end{array}$ & $\begin{array}{l}\text { Açılanan } \\
\text { Varyans \% }\end{array}$ \\
\hline Duyusal Boyut & & 22,408 \\
\hline $\begin{array}{l}\text { Bu markettin ürünleri (görsel, işitsel, dokunsal, kokusal } \\
\text { ya da tatsal) duyularım üzerinde güçlü etkiler bırakır. }\end{array}$ & 0,848 & \\
\hline $\begin{array}{l}\text { Bu markettin ürünlerini duyusal (görsel, işitsel, } \\
\text { dokunsal, kokusal, tatsal) açıdan ilgi çekici buluyorum. }\end{array}$ & 0,803 & \\
\hline $\begin{array}{l}\text { Bu markettin ürünleri duyularımı ve hislerimi harekete } \\
\text { geçirir. }\end{array}$ & 0,671 & \\
\hline $\begin{array}{l}\text { Bu markettin ürünlerini duyularıma (görsel, işitsel, } \\
\text { dokunsal, kokusal, tatsal) hitap eder. }\end{array}$ & 0,61 & \\
\hline Düşünsel Boyut & & 16,468 \\
\hline $\begin{array}{l}\text { Bu markettin ürünleri bana herhangi bir şey } \\
\text { düşündürmez. }\end{array}$ & 0,736 & \\
\hline Bu marketin ürünlerine karşı güçlü duygular beslemem. & 0,696 & \\
\hline $\begin{array}{l}\text { Bu markettin ürünleri ile karşılaştığımda (reklam, } \\
\text { billboard gibi yerlerde) düşüncelere kapılırım. }\end{array}$ & 0,617 & \\
\hline Toplam Açıklanan varyans & & 62,556 \\
\hline
\end{tabular}

Tablo 6.

Satın Alma Ölçeği İçin Açıklayıcı Faktör Analizi Sonuçları (Temel Bileşenler Analizi, Varimax Döndürme, $N=400$ )

\begin{tabular}{lcc}
\hline \multicolumn{1}{c}{ Satın Alma Niyeti } & $\begin{array}{c}\text { Faktör } \\
\text { Yükleri }\end{array}$ & $\begin{array}{c}\text { Açıklanan } \\
\text { Varyans \% }\end{array}$ \\
\hline $\begin{array}{l}\text { Bu marketi büyük olasılıkla arkadaşlarıma tavsiye } \\
\text { edeceğim. }\end{array}$ & $\mathbf{0 , 8 4 4}$ & \\
$\begin{array}{l}\text { Gelecekte bu marketten alışveriş yapmaya devam } \\
\text { edeceğim. }\end{array}$ & $\mathbf{0 , 8 3 8}$ & \\
$\begin{array}{l}\text { Gelecekte de ihtiyacım olan ürünleri bu marketten satın } \\
\text { alacağım. }\end{array}$ & 0,805 & \\
$\begin{array}{l}\text { Bu marketten alışveriş yaparak doğru bir şey yaptığımı } \\
\text { düşünüyorum. }\end{array}$ & 0,79 & \\
$\begin{array}{l}\text { Diğer marketler yerine bu marketten alışveriş yapmanın } \\
\text { daha iyi olduğunu düşünüyorum. }\end{array}$ & 0,751 & \\
Toplam Açıklanan varyans & & $\mathbf{6 4 , 9 8 1}$ \\
\hline
\end{tabular}

\subsection{Güvenilirlik Analizi}

Ölçeğin taşıması gereken özelliklerden birisi olan güvenirlik, bir ölçme aracıyla aynı koşullarda tekrarlanan ölçümlerde elde edilen ölçüm değerlerinin kararlılığının bir göstergesidir. Ölçüm aracının güvenilirliğini
Deneyimsel

Pazarlamanın

Tüketici Satın

Alma Niyeti

Üzerine Etkisi

209 
Deneyimsel

Pazarlamanın

Tüketici Satın

Alma Niyeti

Üzerine Etkisi

210 test etmek için istatistik yöntemler de kullanılabilmektedir. Bu yöntemlerden en yaygını ölçeğin iç tutarlılığını değerlendiren Cronbach's Alpha katsayısı yöntemidir. Bu katsayı, çok sorulu bir ölçekteki sorular arasındaki uyumun derecesini gösterir ve 0 ile 1 arasında değerler alabilir. Cronbach's Alpha katsayısı 1'e yaklaştıkça, ölçekteki sorular arasındaki içsel uyumun o denli yüksek olduğu söylenebilir. Alfa katsayısı,

- $\quad$ 0,80 - 1,00 arasında ise; Ölçek yüksek güvenirliğge sahiptir

- 0,60 - 0,80 arasında ise; Ölçek oldukça güvenilirdir

- 0,40 - 0,60 arasında ise; Ölçek güvenilirliği düşüktür,

- $0-0,40$ arasında ise; Ölçek güvenilir değildir (İslamoğlu ve Alnıaçık, 2014:283).

Tablo 7.

Güvenilirlik Analizi Bulguları (Cronbach's Alpha)

\begin{tabular}{cc}
\hline Faktörler & Cronbach's Alpha \\
\hline Eylemsel Boyut & 0,761 \\
Duyusal Boyut & 0,796 \\
Düşünsel Boyut & 0,608 \\
Satın Alma Niyeti & 0,861 \\
\hline
\end{tabular}

Tablo 9'da faktör analizi ile ayrışan 5 ölçeğin güvenilirlik analizi sonuçlarına ilişkin Cronbach's Alpha katsayıları verilmiştir. Tablo 9'da görüldüğü gibi ölçekler oldukça güvenilirdir.

\subsection{Hipotez Testleri}

H1: Deneyimsel pazarlamanın deneyim boyutları itibariyle cinsiyete göre farklılık göstermektedir.

Katılımcıların cinsiyetleri bakımından, deneyim boyutlarına karşı tutumlarının anlamlı farklılıkların gösterip göstermediğini tespit etmek için, bağımsız iki örneklem $\mathrm{t}$ testi analizinden faydalanılmıştır. Elde edilen özet sonuçlar aşağıdaki Tablo 10'da olduğu gibidir. 
Tablo8.

Katılımcıların Deneyim Boyutlarına Yönelik Tutumlarına İlişkin Grup İstatistikleri

\begin{tabular}{ccccc}
\hline Cinsiyet & N & Ortalama & Std. Sapma & $\begin{array}{c}\text { Ortalamanın standaı } \\
\text { hatası }\end{array}$ \\
\hline Kadın & 235 & 2,9933 &, 65850 &, 04296 \\
Erkek & 165 & 2,9586 &, 74482 &, 05798 \\
\hline \multicolumn{5}{c}{ Tablo 9. } \\
\multicolumn{6}{c}{} \\
Katılımcıların Cinsiyetlerine Göre Deneyim Boyutlarına İlişkin \\
Bağımsız iki Örneklem T Testi Analizi Özet Tablosu \\
\hline \multicolumn{6}{c}{ P } & T & Sig \\
\hline $\begin{array}{l}\text { Deneyim } \\
\text { Boyutları }\end{array}$ & 3,350 &, 068 &, 491 &, 624 \\
\hline
\end{tabular}

H1 hipotezi için yapılan analizde Levene testine ait $\mathrm{p}$ değerleri 0,005'ten büyük $(0,68)$ çıkması varyansların eşit olduğu anlamına gelmektedir. Bu durumda varyansların eşit olduğu birinci satırdaki p (sig (2-tailed)) değerine bakılmıştır. P değerinin (,624) 0,05'ten büyük olması deneyim boyutlarına ilişkin verilen cevapların kadın ve erkeklere göre anlamlı bir farklılık göstermediği anlamına gelmektedir ve H1 hipotezi reddedilmiştir.

H2: Deneyimsel pazarlamanın deneyim boyutları itibariyle yaşa göre farkl1lık göstermektedir.

faydalanılmıştır. Elde edilen özet sonuçlar aşağıdaki Tablo12'de olduğu gibidir.

Tablo 10.

Katılımcıların Yaş Gruplarına Göre Deneyim Boyutlarına İlişkin TekYönlü Varyans (Anova) Analizi Özet Tablosu

\begin{tabular}{lccccccccccc}
\hline \multirow{2}{*}{ Faktörler } & \multicolumn{1}{c}{ Ortalamalar } & \multicolumn{3}{c}{ F } & $\mathbf{P}$ \\
\cline { 2 - 11 } & $18-23$ & $24-29$ & $30-35$ & $36-41$ & $24-47$ & $48-53$ & $54-59$ & $60+$ & \\
\hline Duyusal Boyut & 2,82 & 2,58 & 2,57 & 2,49 & 2,77 & 2,47 & 2,00 & 1,67 & 1,331 &, 234 \\
Duygusal Boyut & 3,30 & 3,18 & 3,10 & 3,14 & 2,83 & 3,20 & 2,67 & 2,33 & 1,007 &, 426 \\
Eylemsel Boyut & 2,83 & 2,83 & 2,92 & 2,75 & 2,73 & 2,87 & 3,00 & 3,00 &, 430 &, 883 \\
Düşünsel Boyut & 2,77 & 2,81 & 2,90 & 2,86 & 3,03 & 2,93 & 2,83 & 2,67 &, 624 &, 736 \\
\hline
\end{tabular}

Yapılan Anova analizi sonucunda önem dereceleri sirasiyla $0,234>0,05,0,426>0,05,0,883>0,05,0,736>0,05$ bulunmuştur ve $\mathrm{H} 2$ hipotezi red edilmiştir yani katılımcıların deneyim boyutları ile yaş grupları arasinda anlamlı bir farklılık yoktur. 
Deneyimsel

Pazarlamanın

Tüketici Satın

Alma Niyeti

Üzerine Etkisi

212

H3: Deneyimsel pazarlamanın deneyim boyutları itibariyle medeni duruma göre farkl1lık göstermektedir.

Katılımcıların medeni durumları bakımından, deneyim boyutlarına karşı tutumlarının anlamlı farklılıkların gösterip göstermediğini tespit etmek için, bağımsız iki örneklem $t$ testi analizinden faydalanılmıştır. Elde edilen özet sonuçlar aşağıdaki Tablo 13'te olduğu gibidir.

Tablo 11.

Katılımcıların Deneyim Boyutlarına Yönelik Tutumlarına İlişkin Grup İstatistikleri

\begin{tabular}{ccccc}
\hline $\begin{array}{c}\text { Medeni } \\
\text { Durum }\end{array}$ & N & Ortalama & $\begin{array}{c}\text { Std. } \\
\text { Sapma }\end{array}$ & $\begin{array}{c}\text { Ortalamanın standart } \\
\text { hatası }\end{array}$ \\
\hline Evli & 81 & 2,8940 &, 69285 &, 07698 \\
Bekâr & 319 & 3,0005 &, 69461 &, 03889 \\
\hline
\end{tabular}

Tablo 12.

Katılımcıların Medeni Durumlarına Göre Deneyim Boyutlarına İlişkin Bağımsız İki Örneklem T Testi Analizi Özet Tablosu

\begin{tabular}{lcccc}
\hline & F & P & T & Sig \\
\hline Deneyim &, 127 &, 722 & 1,233 &, 218 \\
Boyutları & & & 1,235 &, 219 \\
\hline
\end{tabular}

H3 hipotezi için yapılan analizde Levene testine ait $\mathrm{p}$ değerleri 0,005 'ten büyük $(0,722)$ çıkması varyansların eşit olduğu anlamına gelmektedir. Bu durumda varyansların eşit olduğu birinci satırdaki p (sig (2-tailed)) değerine bakılmıştır. P değerinin $(, 218)$ 0,05'ten büyük olması deneyim boyutlarına ilişkin verilen cevapların evli ve bekarlara göre anlamlı bir farklılık göstermediği anlamına gelmektedir ve H3 hipotezi reddedilmiştir.

H4: Deneyimsel pazarlamanın deneyim boyutları itibariyle öğrenim düzeyi göre farklılık göstermektedir.

Eğitim seviyesi bakımından market kullanıcılarının, deneyimsel pazarlamanın deneyim boyutlarına göre tutumlarının anlamlı farklılıkların gösterip göstermediğini tespit etmek için, tek yönlü varyans (Anova) analizinden faydalanılmıştır. Elde edilen özet sonuçlar aşağıdaki Tablo 15 'te olduğu gibidir. 
Tablo 13.

Katılımcıların Öğrenim Düzeylerine Göre Deneyim boyutlarına Tutumlarına İlişkin Tek-Yönlü Varyans (Anova) Analizi Özet Tablosu

\begin{tabular}{|c|c|c|c|c|c|c|c|c|}
\hline \multirow[b]{2}{*}{ Faktörler } & \multicolumn{6}{|c|}{ Ortalamalar } & \multirow[b]{2}{*}{$\mathbf{F}$} & \multirow[b]{2}{*}{$\mathbf{P}$} \\
\hline & İlköğretim & Lise & Önlis & Lisans & $\begin{array}{l}\text { Yüksek } \\
\text { Lisans }\end{array}$ & Doktora & & \\
\hline Duyusal Boyut & 2,00 & 2,67 & 2,37 & 2,66 & 2,69 & 2,87 & 1,59 & 162 \\
\hline Duygusal Boyut & 2,86 & 3,43 & 2,96 & 3,23 & 3,04 & 3,47 & 2,43 & ,035 \\
\hline Eylemsel Boyut & 2,71 & 2,82 & 3,04 & 2,83 & 2,79 & 2,93 & 1,15 & ,335 \\
\hline Düşünsel Boyut & 2,95 & 3,07 & 2,91 & 2,78 & 2,79 & 2,87 & 2,31 & ,044 \\
\hline
\end{tabular}

Yapilan Anova analizi sonucunda önem dereceleri sirasiyla $0,162>0,05, \quad 0,035<0,05, \quad 0,335>0,05, \quad 0,044<0,05$ bulunmuştur. Yapilan analizde, Deneyimsel boyutlardan duygusal boyut ve düşünsel boyutun, öğrenim düzeyleri üzerinde anlamlı bir etkiye sahip olduğu görülmektedir $(035<0,05,0,044<0,05)$ ve $\mathrm{H} 4$ hipotezi Kabul edilmiştir yani katılımcıların öğrenim düzeyleri ile deneyim boyutlarına tutumları arasında anlamlı bir farklılık vardır.

Yapılan Anova analizi sonucunda önem dereceleri $(0,035<0,05$, $0,044<0,05)$ bulunmuştur ve $\mathrm{H} 4$ hipotezi kabul edilmiştir. Yani deneyimsel boyutlar ile öğrenim düzeyleri arasında anlamlı bir farklılık vardır. Bu farklılıkların hangi gruplar arasında olduğunu belirlemek amacıyla çoklu karşılaştırma testlerinden LSD testi yapılarak aşağıdaki bulgular elde edilmiştir.

Tablo 14.

Gruplar Arası Farklılıkların Belirlenmesine Yönelik LSD Analiz Özet

Tablosu

\begin{tabular}{cllrrrr}
\hline & & & $\begin{array}{c}\text { Ortalamaların } \\
\text { farklılıları (I- J) }\end{array}$ & $\begin{array}{c}\text { Standart } \\
\text { hata }\end{array}$ & P \\
\hline & LSD & İlk & Lise & $-0,67424$ & 0,35928 & 0,06 \\
& & Öğretim & Ön lisans & $-0,36937$ & 0,36391 & 0,31 \\
Duyusal & & & Lisans & $-0,66208$ & 0,33903 & 0,05 \\
Boyut & & & Y. Lisans &,$- 68914^{*}$ & 0,34659 & 0,05 \\
& & & Doktora & $-0,86667$ & 0,51699 & 0,09 \\
\hline & LSD & Lise & Lise & 0,30952 & 0,34878 & 0,38 \\
Düşünsel & & & Ön lisans & $-0,26577$ & 0,19119 & 0,17 \\
Boyut & & Lisans & $-0,29664$ & 0,14166 & 0,04 \\
& & & Y. Lisans & $-0,20787$ & 0,15796 & 0,19 \\
& & & Doktora & $-0,3$ & 0,40451 & 0,46 \\
\hline
\end{tabular}

Deneyimsel

Pazarlamanın

Tüketici Satın

Alma Niyeti

Üzerine Etkisi

213 
Deneyimsel

Pazarlamanın

Tüketici Satın

Alma Niyeti

Üzerine Etkisi

214
Tablo $16^{\prime}$ da LSD analizine ait bulgular verilmiştir. Yapılan analiz sonucunda duyusal boyuttaki ilköğretim seviyesindeki katılımcılarla, yüksek lisans seviyesindeki katılımcıların duyusal boyut açısından öğrenim düzeyine göre anlamlı bir farklılık gözlenmektedir.

Düşünsel boyuttaki katılımcılar incelendiğinde lise seviyesindeki katılımcılarla, lisans seviyesindeki katılımcılar arasında düşünsel boyut açısından öğrenim düzeyine göre anlamlı bir farklılık gözlenmektedir.

H5: Deneyimsel pazarlamanın deneyim boyutları itibariyle meslek gruplarına göre farklılık göstermektedir.

Meslek grupları bakımından market kullanıcılarının, deneyimsel pazarlamanın deneyim boyutlarına göre tutumlarının anlamlı farklılıkların gösterip göstermediğini tespit etmek için, tek yönlü varyans (Anova) analizinden faydalanılmıştır. Elde edilen özet sonuçlar aşağıdaki Tablo 17 'de olduğu gibidir.

Tablo 15.

Katılımcıların Meslek Gruplarına Göre Deneyim Boyutlarına Tutumlarına İlişkin Tek-Yönlü Varyans (Anova)Analizi Özet Tablosu

Faktörler

Ortalamalar İşç Eme EvHa Aka Mem Öğr SerMe Esn Diğ F $\quad P$

Not: İşç=İşçi; Eme=Emekli; EvHa=Ev Hanımı; Aka=Akademisyen; Mem=Memur; Öğr=Öğrenci; SerMe=Serbest Meslek; Esn=Esnaf; Di $\breve{g}=$ Diğer

Yapılan Anova analizi sonucunda önem dereceleri sirasiyla $0,000<0,05,0,310>0,05,0,598>0,05,0,627>0,05$ bulunmuştur. Yapilan analizde, Deneyimsel boyutlardan duyusal boyutun, meslek grupları üzerinde anlamlı bir etkiye sahip olduğu görülmektedir $(0,000<0,05)$ ve H5 hipotezi Kabul edilmiştir yani katılımcıların meslek grupları ile deneyim boyutlarına tutumları arasında anlamlı bir farklılık vardır.

Yapılan Anova analizi sonucunda önem dereceleri $(0,000<0,05)$ bulunmuştur ve $\mathrm{H} 5$ hipotezi kabul edilmiştir. Yani deneyimsel boyutlar ile meslek grupları arasında anlamlı bir farklılık vardır. Bu farklılıkların hangi gruplar arasında olduğunu belirlemek amacıyla çoklu karşılaştırma testlerinden LSD yapılarak aşağıdaki bulgular elde edilmiştir. 
Tablo 16.

Gruplar Arası Farklılıkların Belirlenmesine Yönelik LSD Analiz Özet Tablosu

\begin{tabular}{|c|c|c|c|c|c|c|}
\hline & & & & $\begin{array}{c}\text { Ortalamaların } \\
\text { farklılıkları (I- J) }\end{array}$ & $\begin{array}{c}\text { Standart } \\
\text { hata }\end{array}$ & $\mathbf{P}$ \\
\hline \multirow{5}{*}{$\begin{array}{c}\text { Duyusal } \\
\text { Boyut }\end{array}$} & \multirow[t]{5}{*}{ LSD } & \multirow[t]{5}{*}{ İlk Öğretim } & Lise & $-0,67424$ & 0,35928 & 0,061 \\
\hline & & & Ön lisans & $-0,36937$ & 0,36391 & 0,311 \\
\hline & & & Lisans & $-0,66208$ & 0,33903 & 0,052 \\
\hline & & & Y. Lisans &,$- 68914^{*}$ & 0,34659 & 0,047 \\
\hline & & & Doktora & $-0,86667$ & 0,51699 & 0,094 \\
\hline \multirow{5}{*}{$\begin{array}{l}\text { Düşünsel } \\
\text { Boyut }\end{array}$} & \multirow[t]{5}{*}{ LSD } & Lise & Lise & 0,30952 & 0,34878 & 0,375 \\
\hline & & & Ön lisans & $-0,26577$ & 0,19119 & 0,165 \\
\hline & & & Lisans & $-0,29664$ & 0,14166 & 0,037 \\
\hline & & & Y. Lisans & $-0,20787$ & 0,15796 & 0,189 \\
\hline & & & Doktora & $-0,3$ & 0,40451 & 0,459 \\
\hline
\end{tabular}

Tablo $18^{\prime}$ de LSD analizine ait bulgular verilmiştir. Yapılan analiz sonucunda duyusal boyuttaki serbest meslekteki katılımcılarla, işçi, ev hanımı, akademisyen, memur, öğrenci, esnaf ve diğer meslekler arasındaki katılımcıların duyusal boyut açısından mesleklerine göre anlamlı bir farklılık gözlenmektedir.

Yapilan analiz sonucunda duyusal boyuttaki esnaf olan katılımcılarla akademisyen, memur, öğrenci, serbest meslek ve diğer meslekler arasındaki katılımcıların duyusal boyut açısından mesleklerine göre anlamlı bir farklılık gözlenmektedir.

H6: Deneyimsel pazarlamanın deneyim boyutları itibariyle gelir düzeylerine göre farklılık göstermektedir.

Gelir düzeyleri bakımından market kullanıcılarının, deneyimsel pazarlamanın deneyim boyutlarına göre tutumlarının anlamlı farklılıkların gösterip göstermediğini tespit etmek için, tek yönlü varyans (Anova) analizinden faydalanılmıştır. Elde edilen özet sonuçlar aşağıdaki Tablo $19^{\prime}$ da olduğu gibidir.
Deneyimsel

Pazarlamanın

Tüketici Satın

Alma Niyeti

Üzerine Etkisi

215 
Deneyimsel

Pazarlamanin

Tüketici Satın

Alma Niyeti

Üzerine Etkisi

\section{6}

Tablo 17.

Katılımcıların Gelir Düzeylerine Göre Deneyim boyutlarına Tutumlarına İlişkin Tek-Yönlü Varyans (Anova) Analizi Özet Tablosu

\begin{tabular}{|c|c|c|c|c|c|c|c|c|c|}
\hline \multirow[b]{2}{*}{ Faktörler } & \multicolumn{7}{|c|}{ Ortalamalar } & \multirow[b]{2}{*}{$\mathrm{F}$} & \multirow[b]{2}{*}{$\mathrm{P}$} \\
\hline & $\begin{array}{l}1600- \\
2000\end{array}$ & $\begin{array}{c}2001- \\
2500\end{array}$ & $\begin{array}{c}2501- \\
3000\end{array}$ & $\begin{array}{c}3001- \\
3500\end{array}$ & $\begin{array}{c}3501- \\
4000\end{array}$ & $\begin{array}{l}4001- \\
4500\end{array}$ & $\begin{array}{l}4501 \text { ve } \\
\text { Üzeri }\end{array}$ & & \\
\hline $\begin{array}{l}\text { Duyusal } \\
\text { Boyut }\end{array}$ & 2,790 & 2,418 & 2,559 & 2,477 & 2,560 & 2,708 & 2,472 & 1,908 & 0,078 \\
\hline $\begin{array}{l}\text { Duygusal } \\
\text { Boyut }\end{array}$ & 3,298 & 3,0388 & 2,9226 & 3,1556 & 3,0455 & 3,2083 & 3,2545 & 1,947 & 0,072 \\
\hline $\begin{array}{l}\text { Eylemsel } \\
\text { Boyut }\end{array}$ & 2,8 & 2,8837 & 2,8274 & 2,9444 & 3,1212 & 2,8056 & 2,7758 & 1,403 & 0,212 \\
\hline $\begin{array}{l}\text { Düşünsel } \\
\text { Boyut }\end{array}$ & 2,7882 & 2,9767 & 2,8631 & 2,8 & 2,8333 & 2,8194 & 2,8242 & 0,695 & 0,654 \\
\hline
\end{tabular}

Yapılan Anova analizi sonucunda önem dereceleri sirasiyla $0,78>0,05,0,72>0,05,0,212>0,05,0,654>0,05$ bulunmuştur ve H6 hipotezi red edilmiştir yani Katılımcıların deneyim boyutları ile gelir seviyeleri arasında anlamlı bir farklılık yoktur.

H7: Deneyimsel pazarlama boyutlarının, satın alma niyeti üzerinde istatiksel olarak anlamlı bir etkisi vardır.

Regresyon analizi metrik bir bağımlı değişken ile bir veya birden fazla sayıda metrik bağımsız değişken arasındaki ilişkiyi incelemek amacıyla kullanılan bir istatistiksel yöntemdir. Tek bir bağımsız değişkenin kullanıldığı regresyon 'tek değişkenli regresyon analizi' olarak adlandırılır (Altunışık vd., 2012: 233). Çalışmanın amacı doğrultusunda çoklu regresyon analizinden yararlanılması uygun görülmüştür. Araştırma hipotezleri test sonuçları özet tablolar halinde değerlendirilmiş ve tablolaştırılmıştır.

Tablo 18.

Deneyim Boyutları ve Satın Alma Niyeti Arasındaki İlişkiye Ait Regresyon Analizi Sonuçları

\begin{tabular}{cccc}
\hline $\mathbf{R}^{\mathbf{2}}$ & $\mathbf{R}$ & $\mathbf{F}$ değeri & P değeri \\
\hline, 203 &, 451 & 101,509 &, 000 \\
\hline
\end{tabular}

\begin{tabular}{|c|c|c|c|c|c|}
\hline \multirow{2}{*}{ Model } & \multicolumn{2}{|c|}{$\begin{array}{l}\text { Standardize } \\
\text { edilmemiş katsayılar }\end{array}$} & \multirow{2}{*}{$\begin{array}{c}\begin{array}{c}\text { Standardize edilmiş } \\
\text { Katsayılar }\end{array} \\
\text { Beta }\end{array}$} & \multirow{2}{*}{$\mathrm{T}$} & \multirow{2}{*}{ Sig. } \\
\hline & B & $\begin{array}{l}\text { Std. } \\
\text { Hata }\end{array}$ & & & \\
\hline (Sabit) & ,972 & ,144 & & 6,743 & ,000 \\
\hline Deneyim Boyutları & 475 & 047 & ,451 & 10,075 &, 000 \\
\hline
\end{tabular}


Tablo 20'de yer alan veriler incelendiğinde, modele ait $\mathrm{F}$ değerinin 101,509 olduğu ve bu değere ait önem seviyesinin $p<0,001$ olduğu, ayrıca bağımsız değişken olan "Deneyim Boyutları" nın da "Satın Alma Niyeti" üzerindeki etkisinin anlamlı olduğu ( $t=10,075 ; p<0,0001)$ görülmektedir. Böylece H7 hipotezi kabul edilmiştir. Bu nedenle elde edilen regresyon modelinin anlamlı olduğu ve tahminlerde kullanılabileceği sonucuna ulaşılabilir. Yapılan analiz sonucunda deneyimsel pazarlamanın deneyim boyutlarının, satın alma niyeti üzerinde anlamlı bir etkiye sahip olduğu görülmektedir. $(R=0,451)$. Belirlilik katsayısı olan $R^{2}$ ise 0,203 olarak bulunmuştur. Buna göre katılımcıların satın alma niyetine oluşturan tutumun \%20'sı Deneyim boyutlarından kaynaklanmaktadır.

H7'nin alt hipotezleri

H7a: Deneyimsel pazarlamanın duyusal boyutunun tüketici satın alma niyeti üzerine istatistiksel olarak anlamlı bir etkisi vardır.

H7b: Deneyimsel pazarlamanın duygusal boyutunun tüketici satın alma niyeti üzerine istatistiksel olarak anlamlı bir etkisi vardır.

H7c: Deneyimsel pazarlamanın düşünsel boyutunun tüketici satın alma niyeti üzerine istatistiksel olarak anlamlı bir etkisi vardır.

H7d: Deneyimsel pazarlamanın eylemsel boyutunun tüketici satın alma niyeti üzerine istatistiksel olarak anlamlı bir etkisi vardır.

Modelin test edilmesi için Çoklu Regresyon analizi kullanılmıştır. 'Çoklu Regresyon' analiz, bir bağımlı değişkenin ne kadarının bağımsız değişkenler seti tarafından açılanabileceğini ve her bir bağımsız değişkenin göreceli katkısını belirlemede etkilidir (Uygun, 2011).

Tablo 19.

Deneyim Boyutları ve Satın Alma Niyeti Arasındaki İlişkiye Ait Çoklu Regresyon Analizi Sonuçları

\begin{tabular}{ccccc}
\hline Model & $\mathrm{R}^{2}$ & $\mathrm{R}$ & $\mathrm{F}$ değeri & P değeri \\
\hline Duyusal &, 115 &, 339 & 51,734 &, 000 \\
Duygusal &, 118 &, 343 & 53,205 &, 000 \\
Eylemsel &, 176 &, 419 & 84,788 &, 000 \\
Düşünsel &, 235 &, 428 & 93,341 &, 000 \\
\hline
\end{tabular}


Deneyimsel

Pazarlamanın

Tüketici Satın

Alma Niyeti

Üzerine Etkisi

\begin{tabular}{|c|c|c|c|c|c|}
\hline \multirow[t]{2}{*}{ Model } & \multicolumn{2}{|c|}{$\begin{array}{c}\text { Standardize } \\
\text { edilmemiş katsayılar }\end{array}$} & \multirow{2}{*}{$\begin{array}{c}\begin{array}{c}\text { Standardize } \\
\text { edilmiş katsayılar }\end{array} \\
\text { Beta }\end{array}$} & \multirow[b]{2}{*}{$\mathbf{T}$} & \multirow[b]{2}{*}{ Sig. } \\
\hline & B & Std. Hata & & & \\
\hline (Sabit) & 1,649 & 0,108 & & 15,244 & 0,000 \\
\hline Duyusal Boyutları & 0,28 & 0,039 & 0,339 & 7,193 & 0,000 \\
\hline (Sabit) & 1,407 & 0,139 & & 10,153 & 0,000 \\
\hline $\begin{array}{l}\text { Duygusal } \\
\text { Boyutları }\end{array}$ & 0,308 & 0,042 & 0,343 & 7,294 & 0,000 \\
\hline (Sabit) & 1,349 & 0,117 & & 11,492 & 0,000 \\
\hline Eylemsel Boyutları & 0,345 & 0,037 & 0,419 & 9,208 & 0,000 \\
\hline (Sabit) & 1,773 & 0,132 & & 13,434 & 0,000 \\
\hline $\begin{array}{l}\text { Düşünsel } \\
\text { Boyutları }\end{array}$ & 0,42 & 0,32 & 0,53 & 10,831 & 0,000 \\
\hline
\end{tabular}

Bağımlı Değissken: Satın Alma Niyeti.

Tablo 21 incelenmeye devam edildiğinde, duyusal boyut ile satın alma niyeti arasında anlamlı bir ilişkinin olduğu görülmektedir $(R=0,339)$. Belirlilik katsayısı olan $\mathrm{R}^{2}$ ise 0,115 olarak bulunmuştur. Buna göre katılımcıların satın alma niyetinde meydana gelen değişikliğin \%11'i Deneyimsel pazarlamanın duyusal boyutundan kaynaklanmaktadır. Modele ait F değerinin 51,734 olduğu ve bu değere ait önem seviyesinin $\mathrm{p}<$ 0,000 olduğu, ayrıca bağımsız değişken olan "duyusal boyutun" , "satın alma niyeti" üzerindeki etkisinin anlamlı olduğu ( $t=15,244 ; p<0,000)$ görülmektedir. Böylece H7a hipotezi kabul edilmiştir. Bu nedenle elde edilen regresyon modelinin anlamlı olduğu ve tahminlerde kullanılabileceği sonucuna ulaşılabilir.

Duygusal boyut açısından incelendiğinde, duygusal boyut ile satın alma niyeti arasında anlamlı bir ilişkinin olduğu görülmektedir $(R=0,343)$. Belirlilik katsayısı olan $\mathrm{R}^{2}$ ise 0,118 olarak bulunmuştur. Buna göre katılımcıların satın alma niyetinde meydana gelen değişikliğin \%11'i Deneyimsel pazarlamanın duygusal boyutundan kaynaklanmaktadır. Modele ait $\mathrm{F}$ değerinin 53,204 olduğu ve bu değere ait önem seviyesinin $\mathrm{p}<0,000$ olduğu, ayrıca bağımsız değişken olan "duygusal boyutun" un da "satın alma niyeti" üzerindeki etkisinin anlamlı olduğu $(t=10,153 ; p<0,000)$ görülmektedir. Böylece $\mathrm{H} 7 \mathrm{~b}$ hipotezi kabul edilmiştir. Bu nedenle elde edilen regresyon modelinin anlamlı olduğu ve tahminlerde kullanılabileceği sonucuna ulaşılabilir. 
Eylemsel boyut açısından incelendiğinde, eylemsel boyut ile satın alma niyeti arasında anlamlı bir ilişkinin olduğu görülmektedir $(R=0,419)$. Belirlilik katsayısı olan $\mathrm{R}^{2}$ ise 0,176 olarak bulunmuştur. Buna göre katılımcıların satın alma niyetinde meydana gelen değişikliğin \%17'si Deneyimsel pazarlamanın eylemsel boyutundan kaynaklanmaktadır. Modele ait F değerinin 84,788 olduğu ve bu değere ait önem seviyesinin $\mathrm{p}<0,000$ olduğu, ayrıca bağımsız değişken olan "eylemsel boyutun "un da "satın alma niyeti" üzerindeki etkisinin anlamlı olduğu $(t=15,244 ; p<0,000)$ görülmektedir. Böylece H7c hipotezi kabul edilmiştir. Bu nedenle elde edilen regresyon modelinin anlamlı olduğu ve tahminlerde kullanılabileceği sonucuna ulaşılabilir.

Düşünsel boyut açısından incelendiğinde, düşünsel boyut ile satın alma niyeti arasında anlamlı bir ilişkinin olduğu görülmektedir $(R=0,428)$. Belirlilik katsayısı olan $\mathrm{R}^{2}$ ise 0,235 olarak bulunmuştur. Buna göre katılımcıların satın alma niyetinde meydana gelen değişikliğin \%23'ü Deneyimsel pazarlamanın düşünsel boyutundan kaynaklanmaktadır. Modele ait $\mathrm{F}$ değerinin 93,341 olduğu ve bu değere ait önem seviyesinin $\mathrm{p}<0,000$ olduğu, ayrıca bağımsız değişken olan "düşünsel boyutun" un da "satın alma niyeti" üzerindeki etkisinin anlamlı olduğu $(\mathrm{t}=10,831 ; \mathrm{p}<0,000)$ görülmektedir. Böylece $\mathrm{H7d}$ hipotezi kabul edilmiştir. Bu nedenle elde edilen regresyon modelinin anlamlı olduğu ve tahminlerde kullanılabileceği sonucuna ulaşılabilir.

Tablo 20.

Araştırma Modeline Ait Hipotez Sonuçları

\begin{tabular}{lc}
\hline \multicolumn{1}{c}{ Hipotezler } & Sonuç \\
\hline $\begin{array}{l}\text { H1: Deneyimsel pazarlamanın deneyim boyutları itibariyle } \\
\text { cinsiyete göre farklılık göstermektedir. }\end{array}$ & RED \\
$\begin{array}{l}\text { H2: Deneyimsel pazarlamanın deneyim boyutları itibariyle } \\
\text { yaşa göre farklılık göstermektedir. }\end{array}$ & RED \\
$\begin{array}{l}\text { H3: Deneyimsel pazarlamanın deneyim boyutları itibariyle } \\
\text { medeni duruma göre farklılık göstermektedir. }\end{array}$ & RED \\
$\begin{array}{l}\text { H4: Deneyimsel pazarlamanın deneyim boyutları itibariyle } \\
\text { öğrenim düzeyi göre farklılık göstermektedir. }\end{array}$ & KABUL \\
$\begin{array}{l}\text { H5: Deneyimsel pazarlamanın deneyim boyutları itibariyle } \\
\text { meslek gruplarına göre farklılık göstermektedir. }\end{array}$ & KABUL \\
$\begin{array}{l}\text { H6: Deneyimsel pazarlamanın deneyim boyutları itibariyle } \\
\text { gelir düzeylerine göre farklılık göstermektedir. }\end{array}$ & RED \\
$\begin{array}{l}\text { H7: Deneyimsel pazarlama boyutlarının, satın alma niyeti } \\
\text { üzerinde istatiksel olarak anlamlı bir etkisi vardır. }\end{array}$ & KABUL \\
$\begin{array}{l}\text { H7a: Deneyimsel pazarlamanın duyusal boyutunun tüketici } \\
\text { satın alma niyeti üzerine istatistiksel olarak anlamlı bir etkisi vardır. }\end{array}$ & KABUL \\
\hline
\end{tabular}

Deneyimsel

Pazarlamanin

Tüketici Satın

Alma Niyeti

Üzerine Etkisi

219 
Deneyimsel

Pazarlamanin

Tüketici Satın

Alma Niyeti

Üzerine Etkisi

220

Tablo 20. Devamı

\begin{tabular}{lc}
\hline \multicolumn{1}{c}{ Hipotezler } & Sonuç \\
\hline $\begin{array}{l}\text { H7b: Deneyimsel pazarlamanın duygusal boyutunun } \\
\text { tüketici satın alma niyeti üzerine istatistiksel olarak anlamlı bir } \\
\text { etkisi vardır. }\end{array}$ & KABUL \\
$\begin{array}{l}\text { H7c: Deneyimsel pazarlamanın düşünsel boyutunun } \\
\text { tüketici satın alma niyeti üzerine istatistiksel olarak anlamlı bir } \\
\text { etkisi vardır. }\end{array}$ & KABUL \\
$\begin{array}{l}\text { H7d: Deneyimsel pazarlamanın eylemsel boyutunun } \\
\text { tüketici satın alma niyeti üzerine istatistiksel olarak anlamlı bir } \\
\text { etkisi vardır. }\end{array}$ & KABUL \\
\hline
\end{tabular}

\section{Sonuç}

Günümüzde meydana gelen teknolojik gelişmelerle birlikte tüketicilerin yaşam stilleri de değişmektedir. Bu değişim sonucunda kişilerin istek, arzu ve ihtiyaçları da değişime uğramakta ve kişilerin ürün veya hizmetleri satın alma sağlayan sebepler değişmektedir. Bunun doğal sonucu olarak kişilerin satın almasını etkileyen nedenler bulunmalı ve tüketici davranışları pazarlama yöneticileri tarafından dikkatle incelenmelidir. Günümüz tüketicilerinin alışveriş alışkanlıklarında meydana gelen bu değişimin yanında piyasadaki rekabetin çok gelişmesi, ürün çeşitlerinde meydana gelen artış ve ikame ürünler sebebiyle tüketiciler hangi ürün ve hizmetlerin kendi istek, ihtiyaç ve arzularını karşılayacaklarına karar verememektedir. Bunun doğal sonucu olarak tüketiciler ihtiyaç duyup satın almak istedikleri ürün ve hizmetleri deneyerek bilgi sahibi olmak, ürünün onların istek ve ihtiyaçlarını ne kadar karşıladığını görmek isterler.

Tüketicilerin bir ürün veya hizmeti satın alma niyetleri her zaman satın alma davranışılla son bulmamaktadır. İhtiyaç ve isteklerini karşılamak için markete giden bir tüketici ihtiyaç ve isteklerini karşılamadan marketten çıkabilir veya satın alma gerçekleştirebilir. Bunu sağlayan temel sebepler arasında ürünlerin tüketicilere nasıl sunulduğu, mağaza tasarımının kişilere nasıl bir deneyim yaşatacağıyla doğrudan ilintilidir. Satın alma davranışı öncesi deneyim elde etmek isteyen tüketicilerle birlikte, işletmeler ve pazarlama yöneticileri kişilere sunulan deneyimin ürün ve hizmet sektörü için önemini fark etmişlerdir.

Rekabette meydana gelen artış sonucunda işletmeler için deneyimsel pazarlama önemi her geçen gün artmaktadır. Deneyimsel pazarlama uygulamalarının temelinde duyusal, duygusal, eylemsel ve 
düşünsel deneyim boyutları vardır. Deneyim boyutları sadece ürün ve hizmetler hakkında tüketicinin bilgilenmesini sağlamaz, bunun yanında tüketici sadakati ve rekabet avantajı kazandırmaktadır. Her sektör için önemli hale gelmeye başlayan deneyim pazarlama boyutları karlılık ve rekabet avantajlarını kaybetmek işletmeler tarafından dikkate alınmalı ve deneyimsel boyutlar işletmelere uygulanmalıdır. Günümüzde satın almak istedikleri ürün ve hizmetler hakkında deneyim sahibi olmak isteyen tüketicilerin artması dolayısıyla geleneksel pazarlama anlayışı işe yaramamaktadır. Tüketici davranışları ve deneyimsel pazarlamanın sağladığı avantajlar hayatta kalmak isteyen işletmeler için gittikçe daha önemli bir hale gelmektedir.

\section{Sınırlılıklar ve Gelecek Araştırma Önerileri}

Gelecek çalışmalar deneyimsel pazarlamanın ve satın alma niyetine etkisini zincir grupla da indirim marketler çerçevesinde daraltılarak yapılabilir veya karşılaştırılabilir. Aynı çalışma farklı şehir ve örneklemler üzerinde uygulanarak şehirlerarası tüketicilerin farkları iki farklı çalışmayla karşılaştırılabilir.

Çalışmada oluşturulan modele yeni değişkenler eklenerek araştırma geliştirilebilir. Yapısal eşitlik modeli uygulanarak daha ayrıntılı sonuçlara ulaşılabilir. Tüketicilerin deneyimleri lüks ürün veya temel ürün kategorilerinde sınırlandırarak tüketici boyutlarının ürün veya hizmetlerin kalitesine göre etkisinin artıp artmadığı analiz edilebilir. Değişken olarak tüketicinin tekrar satın alma etkisi araştırılarak 2 çalışmanın sonuçları karşılaştırılabilir.

Çalışmada zaman kısıtlarından dolayı, Kişilerin en sık tercih ettikleri ürün grupları ve en sik tercih ettikleri marka sorulmuştur ama çalışmada kişilerin diğer özelliklerine göre karşılaştırılamamıştır. Yeni bir çalışmayla karşılaştııılarak, kişilerin tercihleri ayrıntılı incelenebilir.

Çalışmanın evren ve örneklemi farklı sosyo-demografik özelliklere sahip tüketicilere uygulanabilir. Deneyimsel pazarlamanın boyutlarının web tabanlı teknolojiler üzerindeki deneyimlerinin satın alma niyetine etkisi araştırılıp, çalışmalar arasında karşılaştırma yapılabilir.

Çalışmada deneyim boyutlarından İlişkisel boyut kullanılmamıştır. Gelecek çalışmalarda kullanılarak çalışma derinleştirilebilir. Bunun yanında satın alma niyetini etkileyen faktörlerden kişilik vb. konular kullanılarak araştırma derinleştirilebilir.
Deneyimsel

Pazarlamanın

Tüketici Satın

Alma Niyeti

Üzerine Etkisi

221 
Deneyimsel

Pazarlamanın

Tüketici Satın

Alma Niyeti

Üzerine Etkisi

\section{2}

\section{KAYNAKÇA}

Altunışık, R., R. Coşkun, S. Bayraktaroğlu, E. Yıldırım (2007). Sosyal Bilimlerde Araştırma Yöntemleri. Sakarya: Sakarya Yayıncılık.

Altunışık, R., R. Coşkun, S. Bayraktaroğlu, E. Yıldırım (2010). Sosyal Bilimlerde Araştırma Yöntemleri SPSS Uygulamalı, Sakarya Yayıncllık, 6 Baskı, Sakarya.

Bostanc1, T. (2007). Deneyimsel Pazarlama ve Deneyim Yönetiminin Pazarlama Uygulamalarındaki Yeri ve Duygusal Markalama, Yayımlanmamış Tezsiz Yüksek Lisans Projesi, İzmir: Dokuz Eylül Üniversitesi Pazarlama Programı.

Boswijk A. T., J.P. Thomas, E. Peelen. (2005). A New Perspective on the Experience Economy: Meaningful Experiences, Pearson Education, Amsterdam.

Brakus, J.J., B.H Schmitt, L. Zarantonello, (2009). Brand Experience: What is it? How is it Measured? Does it Affect Loyalty? Journal of Marketing, C:73, s.52-68.

Cronbach, L. J. (1951). Coefficient alpha and the internal structure of tests. psychometrika, 16(3), s. 297-334.

Çiçek B. (2015). Deneyimsel Pazarlama Ve Satın Alma Karar Sürecine Etkisi: Termal Turizm Sektöründe Bir Uygulama, Yayımlanmamış Yüksek Lisans Tezi, Yozgat: Bozok Üniversitesi SBE.

Doğan, H (2006). Müşteri Odaklı Web Sitelerinin Tasarlanması ve Bu Sitelerin Değerlendirilmesine İlişkin bir Uygulama. Yayımlanmamış Yüksek Lisans Tezi, Adana: Çukurova Üniversitesi SBE.

Edvardasın, B., B. Enquist, R. Johnston. (2005). Cocreating Customer Value Through Hyperreality in the Prepurchase Service Experience, Journal of Service Research, 8, 149.

Ekici, N. (2012). Deneyimsel Pazarlama Ve Seyahat Deneyimi: Türk Hava Yolları Örneği. Yayımlanmamış Yüksek Lisans Tezi, Karaman: Karamanoğlu Mehmetbey Üniversitesi SBE

Gilmore, J., J.B. Pine. (2002). Customer Experiences Places: The New Offering Frontier.

İslamoğlu, A. H. (2003). Tüketici Davranışları, Beta Yayıncılık, İstanbul.

İslamoğlu, A. H., Ü. Alnıaçık (2014). Sosyal bilimlerde araştırma yöntemleri, 4. Basım.

İstanbul: Beta Yayınevi.

Karafakioğlu, M. (2008). Uluslararası Pazarlama Yönetimi Teori, Uygulama ve Örnek Olaylar, Beta Yayınları, İstanbul.

Kayasu, T. (2017). Tüketici Davranışları Ve Kahve Akımları Üzerine Bir Araştırma. Yayımlanmamış Yüksek Lisans Tezi, İstanbul: Bahçe şehir Üniversitesi SBE.

Kezer, P. (2012). Postmodern Tüketicinin Değişen Satın Alma Davranışı: İçgüdüsel Alışveriş, Yayımlanmamış Yüksek Lisans Tezi, İzmir: Ege Üniversitesi SBE. 
Kotler P., J.Bowen, J. Makens (1998). Marketing For Hospitality And Tourism, Second Edition, Prentice Hall.

Kurtuluş, K. (2010). Araştırma Yöntemleri. İstanbul: Türkmen Kitapevi.

Pine II, B. J., J.H. Gilmore, (1999). The Experience Economy: Work Is Theatre And Every Business Is A Stage, Boston Mass: HBS Pres.

Pine, J. B., J.H. Gilmore. (July-August 1998). Welcome to the Experience Economy. Harvard Business Review,25-35.

Sağlam, M. (2014). Müşteri Temelli Marka Denkliği Unsurlarının Tüketici Satın Alma Niyeti Üzerine Etkisi: GSM Sektöründe Bir Uygulama, Yayımlanmamış Yüksek Lisans Tezi, İstanbul: İstanbul Ticaret Üniversitesi SBE.

Saltık, I.A. (2011). “Turizm Sektöründe Deneyimsel Pazarlama Ve Tüketici Davranışları Üzerine Etkisi". Yayımlanmamış Yüksek Lisans Tezi, Muğla: Muğla Üniversitesi SBE.

Saygılı, M. (2014). Faydacı Ve Hazcı Alışveriş Motivasyonlarının Online Satın Alma Niyeti Üzerine Etkisi, Yayımlanmış Yüksek Lisans Tezi, Sakarya: Sakarya Üniversitesi SBE.

Schmitt, B. H. (1999b). Experiential Marketing, How to Get Customers to Sense, Feel, Think, Act, Relate, The Free Press, New York.

Schmitt, B. H. (2004), Deneyim Devrimi Capital, Garanti Bonus Akademi, İstanbul.

Schmitt, B. H, (1999). Experiential Marketing, Journal of Marketing Management, 15,53-67.

Solomon, R. M. (2004). Tüketici Krallı̆̆ının Fethi. İstanbul: Mediacat Yayınları. Solomon, M. (2007). Consumer Behavior, Buying, Having and Being, Pearson Prentice Hall, NJ, USA.

Strategy and Leadership, Vol.30, Issue 1, 4-11

Temiztürk, B. (2006). Satış Yeri İletişim Uygulamalarının Tüketici Satın Alma Davranışı Üzerindeki Etkisi. Yayımlanmamış Yüksek Lisans Tezi, Ege: Ege Üniversitesi SBE.

Wilson, D. F, (1998). Why Divide Consumer and Organizational Buyer Behavior?

\footnotetext{
European Journal of Marketing, Sayı: 34, Cilt:7,780-796.
}

Deneyimsel

Pazarlamanın

Tüketici Satın

Alma Niyeti

Üzerine Etkisi

223 
Deneyimsel

Pazarlamanın

Tüketici Satın

Alma Niyeti

Üzerine Etkisi

224

\title{
EFFECT OF EXPERIMENTAL MARKETING ON CONSUMER PURCHASE INTENTION: SAKARYA PROVINCE CASE
}

\author{
EXTENDED ABSTRACT
}

\begin{abstract}
Aim: In this study, it is aimed to explain the effects of experiential marketing on the consumer and the effects on consumer purchasing intent. In line with this purpose, it is aimed to investigate the effect of demographic factors on experiential dimensions and to determine the extent to which experiential marketing affects the consumer's intent to purchase.
\end{abstract}

Method: In this research, a survey was applied to 400 people who shop in the city of Sakarya. While evaluating the survey results, Factor Analysis, T Test, Regression analysis and One-way ANOVA test were applied. The effect of demographic factors on experiential marketing and whether the dimensions of experiential marketing affect purchasing intent were examined. The data were analyzed using SPSS statistical software.

Findings: As a result of the regression analysis, it was supported that the dimensions of experiential marketing had an effect on consumer purchase intent.

In order to test the factor structure of the scales, exploratory factor analysis was performed using the principal components method and varimax rotation. $\mathrm{T}$ test for $\mathrm{H} 1$ and $\mathrm{H} 3$ hypothesis, Anova test for $\mathrm{H} 2, \mathrm{H} 4, \mathrm{H} 5$ and $\mathrm{H} 6$ were analyzed using simple regression and multiple regression for $\mathrm{H} 7$ and sub-hypotheses. Frequency distributions for variables such as demographic information, the most frequently shopping market, the most frequently consumed product group, the most preferred brand in product groups, market preference and shopping frequency were determined.

It has been found that experiential marketing does not differ in terms of experience dimensions by gender, age and marital status. In terms of experience dimensions of experiential marketing, it differs according to education level and professional group. It has been found that experiential marketing does not differ in terms of experience in terms of income levels. Experiential marketing dimensions (sensory, emotional, intellectual and operational) have been found to have a statistically significant effect on purchase intent. 
Results: Experiential marketing dimensions positively affect the consumer purchase intent.

When the data are examined, the F value of the model is 101.509 and the significance level of this value is $p<0.001$, and the effect of the independent variable "Experience Dimensions" on the "Intention to Purchase" is significant $(t=10.075 ; \mathrm{p}<0.0001)$. seen. Therefore, it can be concluded that the regression model obtained is meaningful and can be used in estimates. As a result of the analysis, it is seen that the experience dimensions of experiential marketing has a significant effect on the purchase intent. ( $R=$ 0.451). The $\mathrm{R}^{2}$ with the coefficient of determination was found to be 0.203 . Accordingly, $20 \%$ of the attitude that constitutes the intention of the participants to purchase is due to the Experience dimensions.

Multiple regression model was used to test the sub-hypotheses. It is seen that there is a significant relationship between sensory dimension and purchase intent $(R=0.339) . R^{2}$, which is the coefficient of determination, was found to be 0.115 . According to this, $11 \%$ of the change in participants' intention to purchase arises from the sensory dimension of Experiential marketing. It is seen that the $\mathrm{F}$ value of the model is 51,734 and the significance level of this value is $p<0,000$, and the effect of the independent variable "sensory dimension" on the "purchase intent" is significant $(t=$ $15,244 ; p<0,000)$. Therefore, it can be concluded that the regression model obtained is meaningful and can be used in estimates.

When examined in terms of emotional dimension, it is seen that there is a significant relationship between emotional dimension and purchase intent $(R=0,343)$. The $R^{2}$ with the coefficient of determination was found to be 0.118 . Accordingly, $11 \%$ of the change in participants' intention to purchase arises from the emotional dimension of Experiential marketing. It is observed that the F value of the model is 53,204 and the significance level of this value is $p<0,000$, and the effect of the independent variable "emotional dimension" on the "purchase intent" is significant $(t=10,153$; $p$ $<0,000)$. Therefore, it can be concluded that the regression model obtained is meaningful and can be used in estimates.

When analyzed in terms of the operational dimension, it is seen that there is a significant relationship between the operational dimension and the purchase intent $(\mathrm{R}=0.419)$. The $\mathrm{R}^{2}$ with the coefficient of determination was found to be 0.167 . Accordingly, $17 \%$ of the change in participants' intention to purchase arises from the operational dimension of Experiential marketing. It is seen that the $\mathrm{F}$ value of the model is 84,788 and the significance level of this value is $p<0,000$, and the effect of the independent
Deneyimsel

Pazarlamanin

Tüketici Satın

Alma Niyeti

Üzerine Etkisi 
Deneyimsel

Pazarlamanın Tüketici Satın

Alma Niyeti

Üzerine Etkisi

226 variable "operational dimension" on the "purchase intent" is significant $(\mathrm{t}=$ $15,244 ; \mathrm{p}<0,000)$. Therefore, we conclude that the regression model obtained is meaningful and can be used in estimates.

When examined in terms of intellectual dimension, it is seen that there is a significant relationship between intellectual dimension and purchase intent $(R=0.428)$. The $R^{2}$ with the coefficient of determination was found to be 0.235 . Accordingly, $23 \%$ of the change in participants' intention to purchase arises from the intellectual dimension of Experiential marketing. It is seen that the $F$ value of the model is 93,341 and the significance level of this value is $p<0,000$, and the effect of the independent variable "intellectual dimension" on the "purchase intent" is significant $(t=10,831 ; p<0,000)$. Therefore, it can be concluded that the regression model obtained is meaningful and can be used in estimates.

Keywords: Experiential Marketing, Consumer behavior, Purchasing consumer intention, Customer experience and Marketing experience 